Cornell University Law School Scholarship@Cornell Law: A Digital Repository

$10-2011$

\title{
The Way Forward: Moving From the Post-Bubble, Post-Bust Economy to Renewed Growth and Competitiveness
}

Daniel Alpert

Westwood Capital

Robert C. Hockett

Cornell Law School, Robert-Hockett@lawschool.cornell.edu

Nouriel Roubini

New York University

Follow this and additional works at: http://scholarship.law.cornell.edu/facpub

Part of the Law and Economics Commons

\section{Recommended Citation}

Alpert, Daniel; Hockett, Robert C.; and Roubini, Nouriel, "The Way Forward: Moving From the Post-Bubble, Post-Bust Economy to Renewed Growth and Competitiveness" (2011). Cornell Law Faculty Publications. Paper 1394.

http://scholarship.law.cornell.edu/facpub/1394 


\title{
New America Foundation
}

\section{THE WAY FORWARD \\ Moving From the Post-Bubble, Post-Bust Economy to Renewed Growth and Competitiveness}

\author{
Daniel Alpert, Managing Partner, Westwood Capital \\ Robert Hockett, Professor of Law, Cornell University \\ Nouriel Roubini, Professor of Economics, New York University
}

\section{OCTOBER 2OII}

Notwithstanding repeated attempts at monetary and fiscal stimulus since 2009, the United States remains mired in what is by far its worst economic slump since that of the 1930 s. ${ }^{1}$ More than 25 million working-age Americans remain unemployed or underemployed, the employment-topopulation ratio lingers at a near-historic low of 58.3 percent, ${ }^{2}$ business investment continues at historically weak levels, and consumption expenditure remains weighed down by massive private sector debt overhang left by the bursting of the housing and credit bubble a bit over three years ago. Recovery from what already has been dubbed the "Great Recession" has been so weak thus far that real GDP has yet to surpass its previous peak. And yet, already there are signs of a possible renewed recession.

It is not only the U.S. economy that is in peril right now. At this writing, Europe is struggling to prevent the sovereign debt problems of its peripheral Euro-zone economies from spiraling into a full-fledged banking crisis - an ominous development that would present an already weakening economy with yet another demand shock. Meanwhile, China and other large emerging economies - those best positioned to take up worsening slack in the global economy - are beginning to experience slowdowns of their own as earlier measures to contain domestic inflation and credit-creation kick in, and as weak growth in Europe and the United States dampens demand for their exports.
Nor is renewed recession the only threat we now face. Even if a return to negative growth rates is somehow avoided, there will remain a real and present danger that Europe and the United States alike fall into an indefinitely lengthy period of negligible growth, high unemployment and deflation, much as Japan has experienced over the past 20 years following its own stock-and-real estate bubble and burst of the early 1990s. 3 Protracted stagnation on this order of magnitude would undermine the living standards of an entire generation of Americans and Europeans, and would of course jeopardize America's position in the world. 


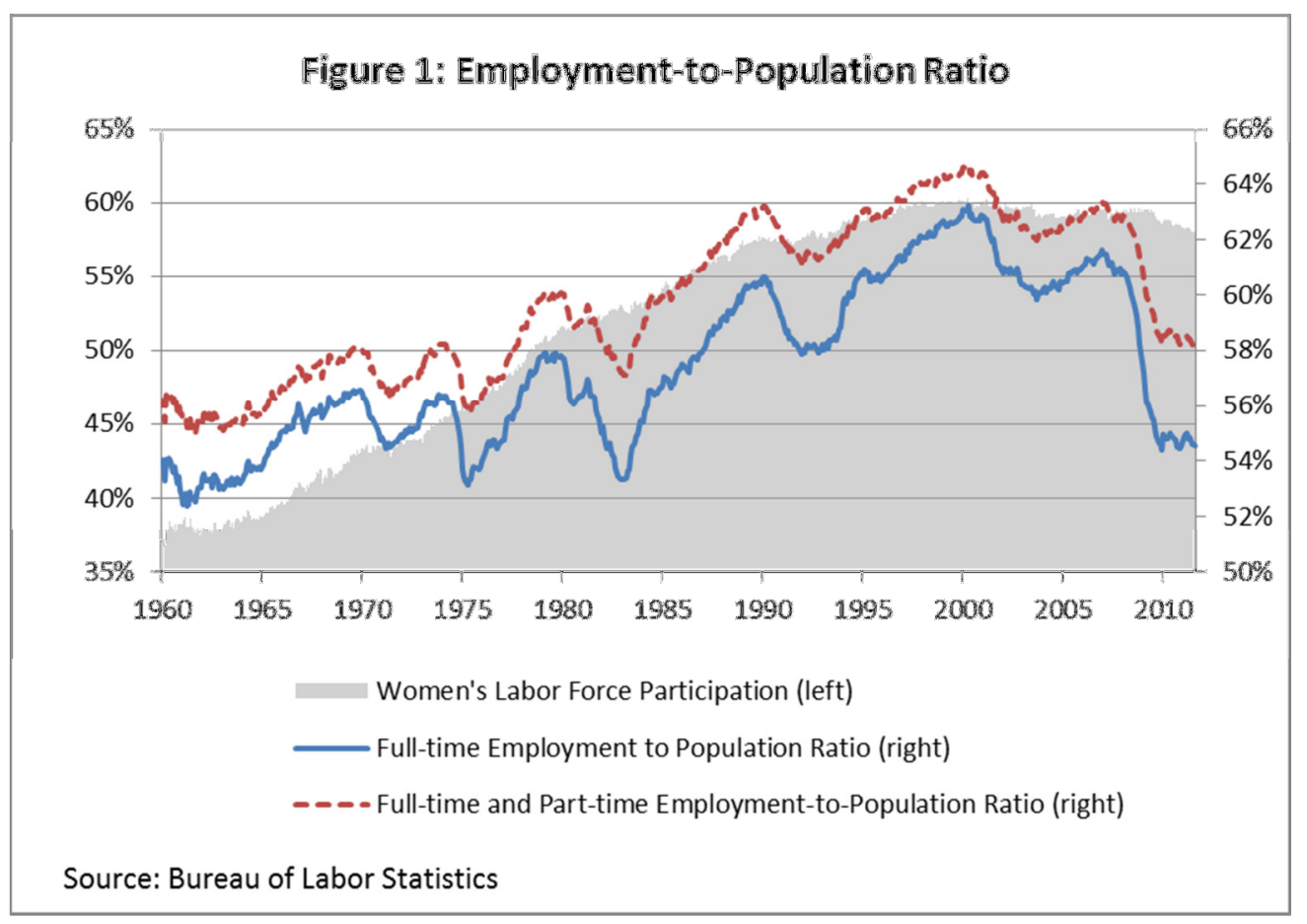

Job Creation Act) and the 2008 Troubled Asset Relief Program to recapitalize the banks.

These actions have undeniably helped stabilize the economy-temporarily. But as evidenced by continuing high unemployment and the weak and now worsening economic outlook, they have not produced a sustainable recovery. And there is no reason to believe that further such measures now being proposed, including the additional tax relief and modest spending found in the administration's proposed American Jobs Act - which look all too much

Our economic straits are rendered all the more dire, and the just mentioned scenario accordingly all the more likely, by political dysfunction and attendant paralysis in both the United States and Europe. The political stalemate is in part structural, but also is attributable in significant measure to the nature of the present economic crisis itself, which has stood much familiar economic orthodoxy of the past 30 years on its head. For despite the standoff over raising the U.S. debt ceiling this past August, the principal problem in the United States has not been government inaction. It has been inadequate action, proceeding on inadequate understanding of what ails us.

Since the onset of recession in December 2007, the federal government, including the Federal Reserve, has undertaken a broad array of both conventional and unconventional policy measures. The most noteworthy of these include: slashing interest rates effectively to zero; two rounds of quantitative easing involving the purchase of Treasuries and other assets, followed by Operation Twist to flatten the yield curve yet further; and three fiscal stimulus programs (including the 2008 Economic Stimulus Act, the 2009 American Recovery and Reinvestment Act, and the 2010 Tax Relief, Unemployment Insurance Reauthorization, and like previous measures - will be any more successful. Indeed, there is good reason to worry that most of the measures tried thus far, particularly those involving monetary reflation, have reached the limits of their effectiveness.

The questions now urgently before us, then, are these: First, why have the policies attempted thus far fallen so far short? And second, what should we be doing instead?

Answering these questions correctly, we believe, requires a more thorough understanding of the present crisis itself its causes, its character, and its full consequences.

Regrettably, in our view, there seems to be a pronounced tendency on the part of most policymakers worldwide to view the current situation as, substantially, no more than an extreme business cyclical decline. From such declines, of course, robust cyclical recoveries can reasonably be anticipated to follow in relatively short order, as previous excesses are worked off and supply and demand find their way back into balance. And such expectations, in turn, tend to be viewed as justifying merely modest policy measures. 
Yet as we shall show in what follows, this is not an ordinary business cycle downturn. Two features render the present slump much more formidable than that - and much more recalcitrant in the face of traditional policy measures.

First, the present slump is a balance-sheet Lesser Depression or Great Recession of nearly unprecedented magnitude, occasioned by our worst credit-fueled assetprice bubble and burst since the late 1920 . ${ }^{4}$ Hence, like the crisis that unfolded throughout the 1930s, the one we are now living through wreaks all the destruction typically wrought by a Fisher-style debt-deflation. In this case, that means that millions of Americans who took out mortgages over the past 10 to 15 years, or who borrowed against the inflated values of their homes, are now left with a massive debt overhang that will weigh down on consumption for many years to come. And this in turn means that the banks and financial institutions that hold this debt are exposed to indefinitely protracted concerns about capitalization in the face of rising default rates and falling asset values.

But there is more. Our present crisis is more formidable even than would be a debt-deflation alone, hard as the latter would be. For the second key characteristic of our present plight is that it is the culmination of troubling trends that have been in the making for more than two decades. In effect, it is the upshot of two profoundly important but seemingly unnoticed structural developments in the world economy.

The first of those developments has been the steady entry into the world economy of successive waves of new exportoriented economies, beginning with Japan and the Asian tigers in the 1980 and peaking with China in the early 2000s, with more than two billion newly employable workers. The integration of these high-savings, lower wage economies into the global economy, occurring as it did against the backdrop of dramatic productivity gains rooted in new information technologies and the globalization of corporate supply chains, decisively shifted the balance of global supply and demand. In consequence, the world economy now is beset by excess supplies of labor, capital, and productive capacity relative to global demand. This profoundly dims the prospects for business investment and greater net exports in the developed world - the only other two drivers of recovery when debt-deflation slackens domestic consumer demand. It also puts the entire global economy at risk, owing to the central role that the U.S. economy still is relied on to play as the world's consumer and borrower of last resort.

The second long term development that renders the current debt-deflation, already worse than a mere cyclical downturn, worse even than other debt-deflations is this: The same integration of new rising economies with ever more competitive workforces into the world economy also further shifted the balance of power between labor and capital in the developed world. That has resulted not only in stagnant wages in the United States, but also in levels of income and wealth inequality not seen since the immediate pre-Great-Depression 1920 s.

For much of the past several decades, easy access to consumer credit and credit-fueled rises in home values themselves facilitated by recycled savings from emerging economies' savings - worked to mask this widening inequality and support heightening personal consumption. But the inevitable collapse of the consumer credit and housing price bubbles of course brought an end to this pattern of economic growth and left us with the massive debt overhang cited above. Government transfer payments and tax cuts since the crash have made up some of the difference over the past two years; but these cannot continue indefinitely and in any event, as we argue below, in times like the present they tend to be saved rather than devoted to employment-inducing consumer expenditure. Even current levels of consumption, therefore, will henceforth depend on improvements in wages and incomes. Yet these have little potential to grow in a world economy beset by a glut of both labor and capital. 
Only the policymakers of the 1930s, then, faced a challenge as complex and daunting as that we now face.

Notwithstanding the magnitude of the challenge, however, this paper argues that there is a way forward. We can get past the present impasse, provided that we start with a better diagnosis of the crisis itself, then craft cures that are informed by that diagnosis. 5 That is what we aim here to do. The paper proceeds in five parts:

Part I provides a brief explanatory history of the credit bubble and bust of the past decade, and explains why this bubble and bust have proved more dangerous than previous ones of the past 70 years.

Part II offers a more detailed diagnosis of our present predicament in the wake of the bubble and bust, and defines the core challenge as of the product of necessary delevering in a time of excess capacity.

Part III explains why the conventional policy tools thus far employed have proved inadequate - in essence, precisely because they are predicated on an incomplete diagnosis. It also briefly addresses other recently proposed solutions and explains why they too are likely to be ineffective and in some cases outright counterproductive.

Part IV outlines the criteria that any post-bubble, post-bust recovery program must satisfy in order to meet today's debt-deflationary challenge under conditions of oversupply.

Part $V$ then lays out a three-pillared recovery plan that we have designed with those criteria in mind. It is accordingly the most detailed part of the paper. The principal features of the recovery plan are as follows:

First, as Pillar 1, a substantial five-to-seven year public investment program that repairs the nation's crumbling public infrastructure and, in so doing, (a) puts people back to work and (b) lays the foundation for a more efficient and cost-effective national economy. We also emphasize the substantial element of "selffinancing" that such a program would enjoy, by virtue of (a) massive currently idle and hence low-priced capacity, (b) significant multiplier effects and (c) historically low government-borrowing costs.

Second, as Pillar 2, a debt restructuring program that is truly national in scope, addressing the (intimately related) banking and real estate sectors in particular - by far the most hard-hit by the recent bubble and bust and hence by far the heaviest drags on recovery now. We note that the worst debt-overhangs and attendant debt-deflations in history ${ }^{6}$ always have followed on combined real estate and financial asset price bubbles like that we have just experienced. Accordingly, we put forward comprehensive debt-restructuring proposals that we believe will unclog the real estate and financial arteries and restore healthy circulation - with neither overly high nor overly low blood pressure - to our financial and real estate markets as well as to the economy at large.

Third, as Pillar 3, global reforms that can begin the process of restoring balance to the world economy and can facilitate the process of debt de-levering in Europe and the United States. Key over the next five to seven years will be growth of domestic demand in China and other emerging market economies to (a) offset diminished demand in the developed world as it retrenches and trims back its debt overhang, and (b) correct the current imbalance in global supply relative to global demand. Also key will be the establishment of an emergency global demand-stabilization fund to recycle foreign exchange reserves, now held by surplus nations, in a manner that boosts employment 
in deficit nations. Over the longer term, we note, reforms to the IMF, World Bank Group, and other institutions are apt to prove necessary in order to lend a degree of automaticity to currency adjustments, surplusrecycling, and global liquidity-provision. ${ }^{7}$

Part V is then followed by a brief conclusion.

\section{Part I: How We Got Here: Bust from Bubble, Toil and Trouble}

"How we got here" is in essence the story of how, over the course of several decades, a series of positive global supplyside shocks together with poor policy choices led to the largest credit-fueled asset price bubble since that of the 1920 s. The story begins with the entry into an ever more integrated global economy of literally billions of new workers, as formerly closed economies like those of China and India opened themselves to international trade and investment. Over the past 20 years, thanks in part to the end of the Cold War and in part to new communications technologies that fostered an integrated global supply chain, nearly three billion workers from China, India, the former Socialist economies in Eastern Europe, and other emerging markets have steadily been joining the global free market labor force. This followed on the heels of an earlier but smaller such integration - that of the export-oriented economies of Japan, South Korea, and the other Asian tigers in the 1980 s and early 1990s. Like Japan and some of the other Asian tigers, many of these economies, particularly China, have pursued economic development models that emphasize high savings and export-oriented manufacturing, and whose economic growth has accordingly been driven more by investment and exports than by domestic consumption.

The integration of China and other lower-wage emerging economies occurred at the same time as a dramatic increase in productivity growth rooted in the information technology revolution and the deployment of IT in global manufacturing. It also took place at a time of increasing international financial integration that allowed for more cross-border investment, including both long-term foreign direct investment and shorter term portfolio capital flows. The overall effect was to create successive waves of investment booms in these newly industrializing economies-first in the Asian tigers, then in China, and now increasingly in other emerging economies-which dramatically expanded global productive capacity.

The steady integration of these new export-oriented economies into the world economy brought three dramatic consequences. First, as noted in the Introduction, it shifted the balance of global supply and demand, leading to a state of affairs in which global productive capacity in many tradable sectors - with the possible exception of energy and foodstuffs - outstrips effective demand. In a remarkably short span of time, the integration of China, India, and other large emerging economies into the global economy more than doubled the world's effective labor supply. Productive capacity also increased via investment, as the new emerging economies maintained higher savings and investment rates than did the advanced industrialized economies of Europe and the United States.

Despite the efficiency gains inherent in greater specialization of the sort wrought by globalization, this transfer of productive capacity from advanced industrialized economies like the United States had the effect of replacing higher wage U.S. workers with lower wage workers in China and other emerging economies, thereby reducing effective consumer demand relative to supply. The spread of the IT-related productivity revolution also added to the imbalance between supply and demand. For in many economies, including the United States and the large producer-oriented Asian economies, productivity growth for the last decade or more increased more rapidly than wages, resulting in a loss of overall consumer purchasing power relative to supply. 


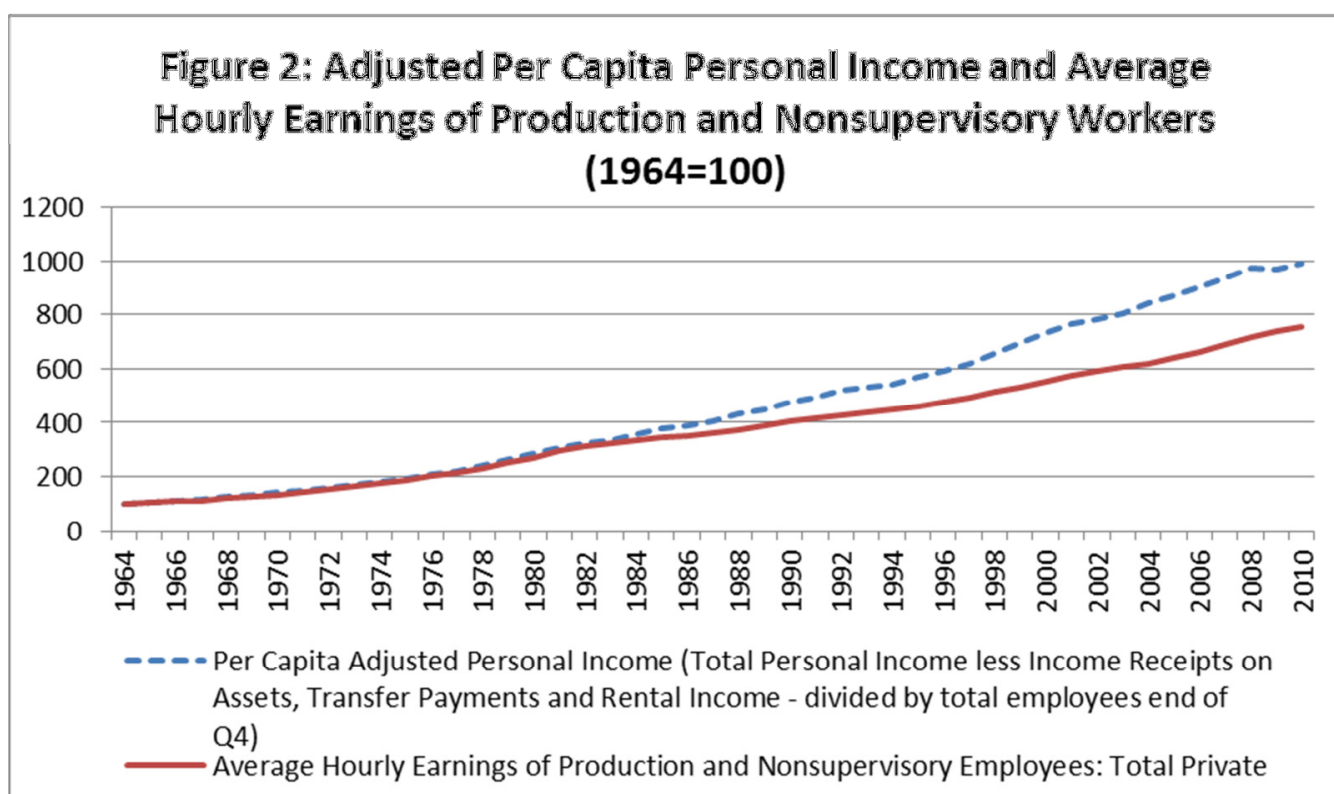

Source: authors calculations, Bureau of Labor Statistics, and Bureau of Economic Analysis wage and salary income earned by the supervisory and other, more well-compensated, workers. But the problem went beyond bifurcated wages. It also involved a major change in the shares of income received by labor and capital. Because many workers were no longer sharing the fruits of the economy's impressive productivity gains, capital was able to claim a much larger share of the returns, further widening wealth and income inequality which by 2008 had reached levels not seen since the fateful year of 1928.
The second consequence of the pattern of global integration that we are highlighting, as suggested above, was to put billions of new low-wage workers in emerging economies into (a) direct competition with millions of higher wage workers in the United States and (b) indirect competition with millions more by virtue of the dislocations that direct competition caused in the U.S. labor market. The predictable result of this new competition, especially at a time of rapid productivity growth and weak bargaining power on the part of labor, was to erode the wages and incomes of workers - particularly lower skilled blue collar workers in the developed world, but now increasingly middle-income workers in the "off-shorable" part of the white collar workforce as well.

All of this bore the further consequence of exacerbating a trend toward wider income disparities in the United States that already had been steadily growing since the early 1980 s. $^{8}$ Figure 2, above, illustrates the growth of the wage gap, almost non-existent prior to the 1980 , between production and non-supervisory workers - some 82 percent of all non-farm wage and salary workers - and the total wage and salary component of personal income for all workers. The gap between the blue and red lines includes
The third consequence of the pattern of globalization we are highlighting has to do with global capital flows, and the role that they played in the recent consumer credit and housing bubbles. Up to the early 1990 s, capital generally flowed from the advanced industrialized economies to the developing world-the exception being the recycling of OPEC oil surpluses during the 1970s and intermittently since then. But with the globalization of production and finance in the late 1990s, that familiar pattern began to change.

There were two important facets of this change. One was the fact that China and other high-savings, export-oriented economies began to run current account surpluses as more and more developed-country companies began to locate production there to take advantage of lower wage costs, while, correspondingly, lower-savings, liberal economies like the United States and Britain began to run larger trade and current account deficits. The U.S. current account deficit increased from an average of 1.6 percent of GDP in the 1990 s to more than 6 percent at the height of the housing and credit bubble. Meanwhile, China moved from 
a small current account deficit in the late 1990 os to a current surplus of more than 10 percent of GDP.

The other facet of the change in the direction of capital flows stems from the lesson that emerging economies drew from the 1997-98 financial crisis-namely, that in order to protect themselves from sudden reversals of short-term capital flows, they had either to impose capital controls or to build up large holdings of foreign exchange reserves. Most relatively large, open emerging economies - Brazil, for example - chose the latter course, in what came to be recognized as a form of self-insurance against volatile international capital flows. This of course meant that these countries, too, sent capital to the United States, in order to accumulate Treasuries and other dollar-denominated assets.

Together, these two developments - the rise of large exportled growth economies and the growth of dollardenominated foreign exchange accumulation - set the stage for a remarkable reversal in the traditional direction of capital flows at the turn of the millennium. To be sure, capital in the form of direct foreign investment still flowed from the United States to emerging markets in order to take advantage of the massive imbalance in labor costs, but an even greater quantum of shorter term capital began to move in the other direction, much of it into the U.S. bond market, which of course exerted downward pressure on interest rates. These "reverse" net capital flows led to an excess of financial capital in the developed world - easily the most fateful result of that huge "global savings glut" noted by then Federal Reserve Board Governor Ben Bernanke in 2005 .
It was this glut which, together with the loosening of financial regulation and lending standards, provided much of the fuel to that credit and housing bubble which came to define the first decade of the $21^{\text {st }}$ century. The effect of this excess capital on interest rates was further exacerbated by the easy monetary stances that the Federal Reserve and the Bank of Japan felt compelled to maintain in the face of weak economic growth, the bursting of the NASDAQ bubble, and the challenges to economic confidence posed by the devastating events of September 11, 2001. It is regrettable that these developments did not prompt policymakers to rethink their heavy emphasis on supplyside policies over the previous decade or two. It is equally regrettable that instead we saw a doubling down on these policies, combined with easier monetary policy and an expansion of credit meant to offset the loss of income by middle class workers. In effect, these policies amounted to a totally impractical "supply-side Keynesianism" that led to ever more borrowing meant to compensate for dwindling consumer demand no longer supported by real wages and incomes.

These trends—global excess capacity, stagnant wages with rising income and wealth inequality, and global

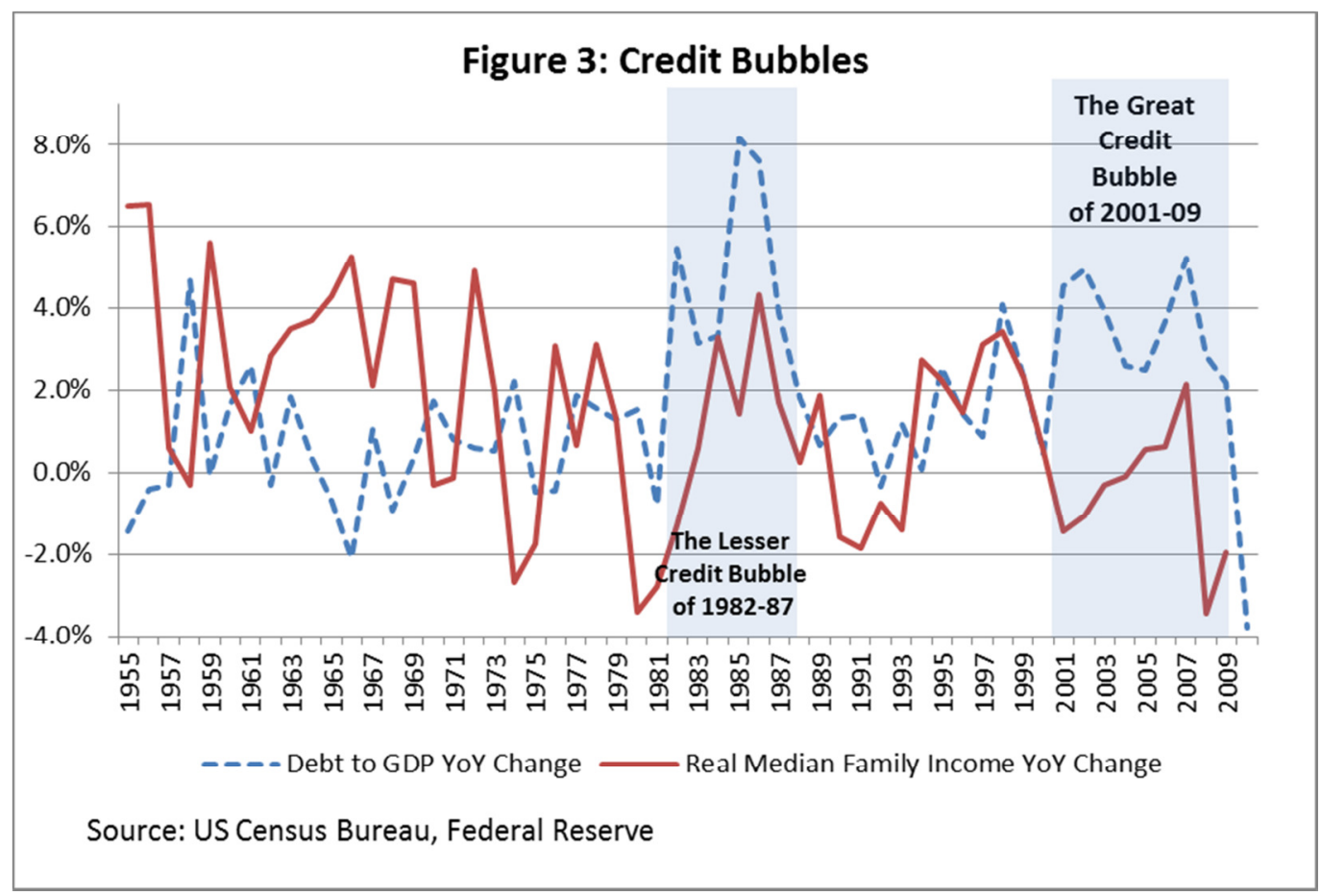




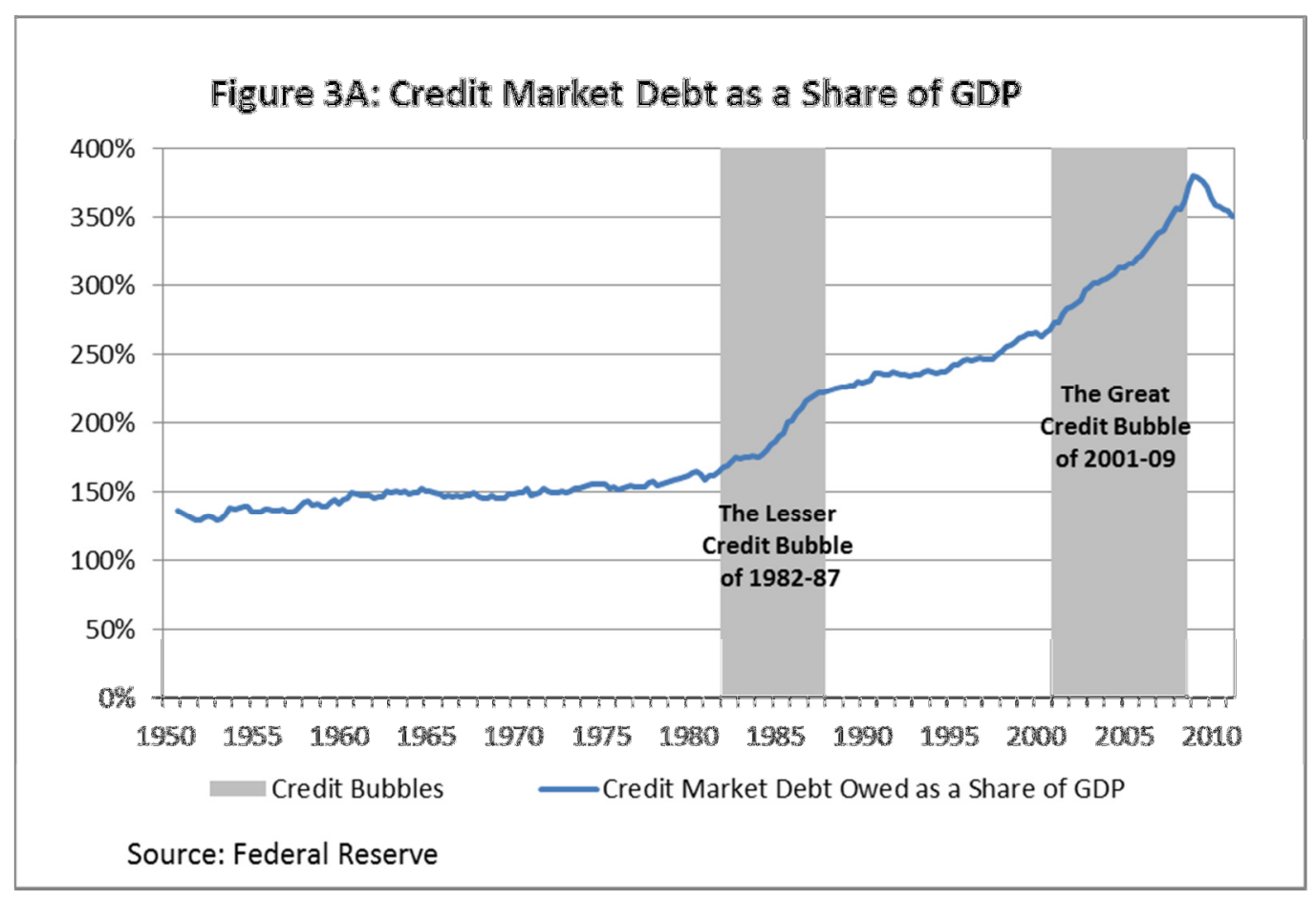

as a major cyclical downturn, it also coincided with the emergence of the first meaningful challenge to U.S. post-war economic dominance, that from Japan. But there the comparison of these two postWar credit bubbles ends. As Figure 3 demonstrates, during the Lesser Credit Bubble, as during all times prior to the past decade, changes to real Median Family Income (MFI) either exceeded or were commensurate with changes in the domestic total debt to GDP ratio. By contrast, during the Great Credit

imbalances-all came together with a vengeance to create one of the largest and most destructive credit bubbles in world economic history. The magnitude of what we call the "Great Credit Bubble of 2001-09" can be seen by comparing it to earlier credit excesses. As Figure 3 shows, the U.S. economy has experienced two significant credit bubbles over the past 55 years. 9 But the Great Credit Bubble of 2001-2009 was an event much different in magnitude and even in kind from the credit bubbles of other recent periods - including the most comparable period, that of what we label "The Lesser Credit Bubble of 1982-1987."

The two bubbles were similar in that they were part of a general supply-side-enhanced response to what was perceived as a major cyclical downturn. The Lesser Credit Bubble of 1982-87 coincided with the emergence of the first meaningful challenge to U.S. post-war economic dominance, that from Japan, while the Great Credit Bubble coincides with the rapid integration of China into the global economy.

While the Lesser Credit Bubble was part of a general supply-side enhanced response to what was then perceived
Bubble of 2001-2009, real median incomes fell, on both an average annual basis and in the aggregate. Accordingly, one could correctly call the Lesser Credit Bubble a "creditfueled expansion," while the Great Credit Bubble is more aptly described as "credit-fueled destruction."

Yet there is another major difference, of great significance, between the Lesser and Greater Credit Bubbles, and that involves what happened to real Household Net Worth (HNW) during these two periods. As shown in Figure 4 on the following page, Real Household Net Worth soared during the Great Credit Bubble, but it has since returned to a level last seen in 2000 at the beginning of the bubble period. Never before has the U.S. seen a decadal, or indeed anywhere near a decade of, retreat in real household net worth. Not during the oil crisis of the 1970s, not after the Lesser Credit Bubble, and not after the internet bubble. This suggests that something very different, and something indeed very worrying, has recently been afoot.

The difference is the inability of the United States this time to channel the supply of excess capital that generated ephemeral bubble-era growth into real growth in common incomes and, ultimately, wealth. This inability, in turn, 


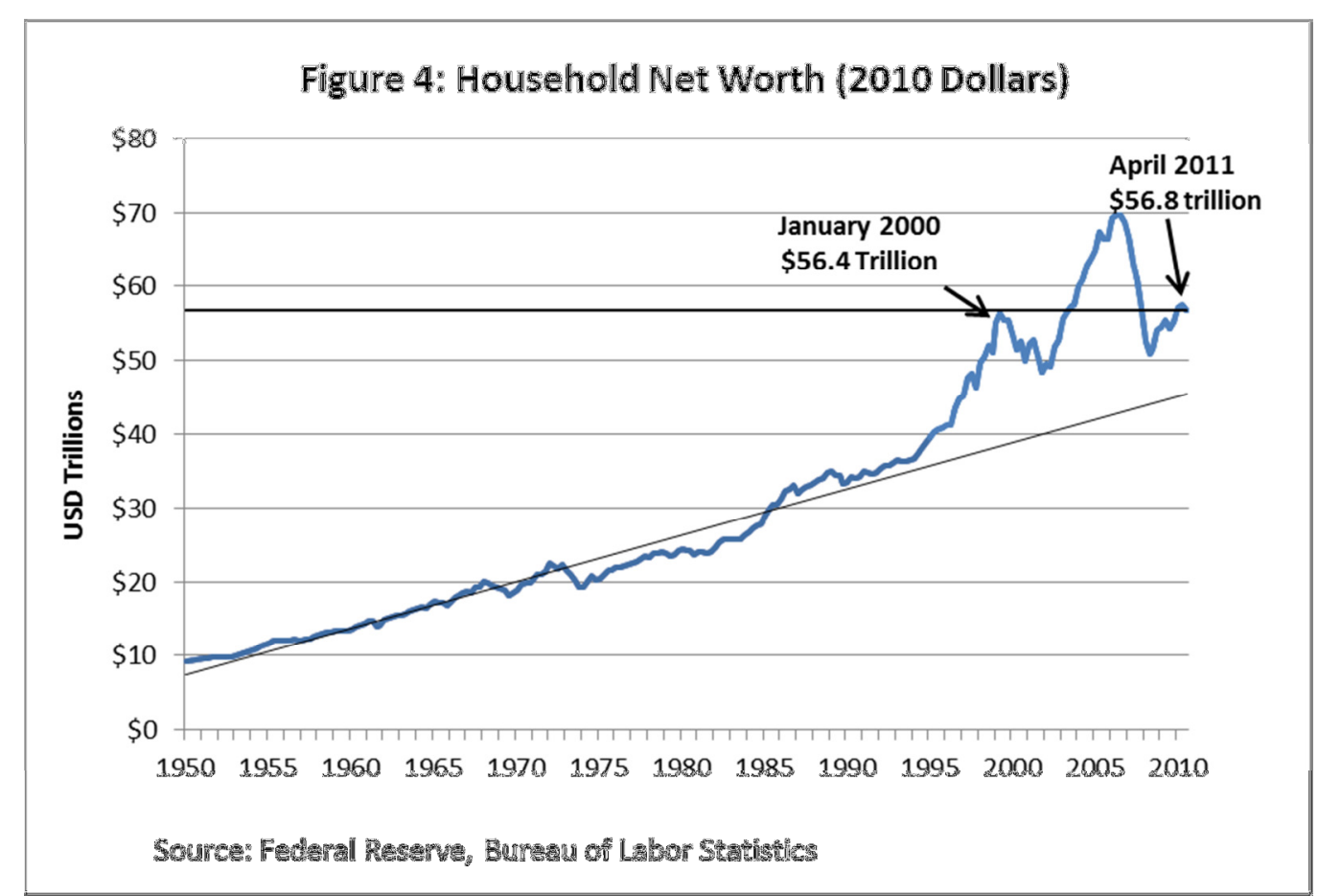

stems from the same overhang of labor and capacity that generated the excess of global capital to begin with.

The statistics that underlie the graphs in Figures 3, 3A and 4 are summarized as follows:

\section{Figure 5: A Tale of Two Credit Bubbles}

\section{Credit Bubble of 1982 through 1987}

Avg Rate of Debt to GDP Growth

Avg Rate of Real MFI Change

Avg Rate of Real HNW Growth

Aggregate Debt to GDP Growth

Aggregate Real MFI Change

Aggregate Real HNW Growth

Credit Bubble of 2001 through 2009

Avg Rate of Debt to GDP Growth

Avg Rate of Real MFI Change

Avg Rate of Real HNW Growth

Aggregate Debt to GDP Growth

Aggregate Real MFI Change

Aggregate Real HNW Growth
$5.27 \%$

$1.68 \%$

$4.96 \%$

$28.86 \%$

$11.85 \%$

$30.00 \%$

$3.61 \%$

$-0.55 \%$

$0.69 \%$

$31.55 \%$

$-3.52 \%$

$4.22 \%$ bubble-time, pre-bust levels, leaving governments to take up the slack.

\section{Part II: Defining the Challenge: The Great De-levering in a Time of Excess Global Capacity}

The previous section explains why the challenge now confronting U.S. policy-makers is much greater than is conventionally recognized. The challenge is not how to respond to an unusually severe cyclical downturn, but how to deal with the bursting of the largest and most destructive credit bubble of the last 70 years, all while repairing what is broken in the U.S. and world economies that ultimately caused the bubble in the first place.

The bursting of the Great Credit Bubble has left the U.S. and European economies with massive debt overhangs. In the United States, debt as a percentage of GDP increased from 247 percent of GDP in 1996 to a peak in 2009 of 380 percent. Household and financial sector debt have accounted for the lion's share of the increase, although compensatory government debt also has been rising more rapidly since the bubble burst in 2008 . Household debt 
climbed from 65 percent of GDP in 1996 to 99 percent in the first quarter of 2009. Financial sector debt rose from 59 percent of GDP in 1996 to 123 percent in the first quarter of 2009 .

The debt overhang in both sectors has more or less stabilized for now, and the household sector has actually made some modest progress in reducing its overall indebtedness.

But in spite of this progress, both sectors are facing years of balance sheet repair, and there remains a serious risk of protracted debt-deflation. Debt-deflation occurs when underlying variable asset values fall while fixed nominal debt values remain at their bubble-time, pre-bust levels. That's where we are now. Indeed, we are still in the early middle innings of what will be a multi-year debt-delevering process. Housing prices and other asset values are still adjusting to the new economic realities, and could fall further if the economy falters yet again and unemployment increases yet more.

Even if the worst of a debt-deflation is avoided, the process of de-levering will constitute an ongoing drag on aggregate demand and economic growth. De-levering destroys demand as households save more and consume less in order to pay down debt. In this case, the effect on consumption will be magnified by the absence of credit and asset-price rises of the kind that supported consumption prior to the collapse. With rising asset values, households were able to tap more credit to support consumption. They also felt wealthier and thus tended to spend more and save less. But credit-expansion and the wealth effect have now gone into reverse. And households will feel compelled to save even more to compensate for declines in their retirement savings and underlying property values. Meanwhile businesses will remain reluctant to invest and add capacity until they see the outlook for aggregate demand improve, and until overcapacity in housing and other sectors is worked off.
The overarching challenge, then, is how to de-lever in a way that avoids worsening debt-deflation and corrects the serious imbalance between supply and demand in the global economy. This challenge is made all the more difficult by four additional factors that threaten to clog up the normal channels of economic recovery.

First, the rise in income and wealth inequality described in the earlier section will continue to worsen the aggregate demand problem and constitute an obstacle to economic recovery efforts - especially efforts that rely too heavily on monetary reflation and quantitative easing, since these measures tend principally to benefit asset owners while increasing the day-to-day costs of ordinary working Americans. ${ }^{10}$ Since, as noted above, income has shifted from labor to capital, from households to corporate firms, and from wages to profits, there has been an unremitting fall in aggregate demand. For households' and workers' marginal propensities to spend are higher than are those of firms and capital investors, meaning that redistribution from the former to the latter as has happened over the past several decades tends disproportionately to lessen demand. This is an issue not just in the U.S., but also in China and most of emerging Asia as well as in Japan and Germany, where wages have grown much more slowly than productivity for a very long period of time.

Second, especially in the U.S., labor cost cutting by the corporate sector in response to the crisis also exacerbates the slow growth problem. Firms are not hiring, and keep firing, so as to "survive and thrive" and achieve earnings forecasts. But one firm's labor costs are another firm's - or household's - labor income. So what is rational at the individual firm level - slashing labor costs in the face of revenue declines to stay profitable - in the aggregate proves perverse. We are, in other words, in collective action problem territory again. If companies don't hire and actually fire because there is excess capacity and lack of final demand, their behavior results in little to no job creation and considerable job loss, little to no labor income growth and indeed likely loss, and consequently reduced 
consumer confidence, consumption, and final demand. Ultimately, even the profit share in income will cease to rise further as labor-cost- cutting, which might beef up the bottom line in the short run, destroys it in the long run by lowering top line sales and revenues.

Third, as if to add insult to injury, economic recovery in the United States and other parts of the advanced industrialized world will face significant demographic headwinds in the form of aging populations. While demography is of course not our principal concern in this paper, the demographic change does render the problems that concern us all the more poignant. In the United States, for example, demographic change means retirement of the Baby Boom generation, hence a sustained reduction of the impact that this cadre has hitherto had on consumer demand and asset values. In Japan and in some portions of Europe, it portends something even worse - actual depopulation and all that this means for domestic consumer and investment demand, not to mention pension funding.

Finally, successful de-levering depends in part upon global rebalancing. Surplus economies must expand demand in order for the United States to consume less and produce more. But the Euro-zone is also trying to de-lever, and in a way that will further depress global aggregate demand. Germany seems determined to impose austerity policies upon European debtor economies without itself taking offsetting policies to expand demand, thereby creating a one-way deflationary adjustment. This places the full onus of global demand-sustenance upon China and emerging Asia. But these economies seem either wedded to their export-oriented economies or unable to adjust rapidly enough. China continues to resist letting its currency appreciate in any meaningful way, forcing other emerging economies to try to control their currencies or otherwise face a loss of competitiveness. Even if these economies more fully pursue domestic demand-led growth, rebalancing takes time. It involves not just more expansionary macroeconomic policy but longer term structural changes, and it takes time to develop social safety nets and mass consumer markets.

The overall effect of these multiple factors has been to render the demand hole opened by the bursting of the Great Credit Bubble all the larger. For much of the past decade plus, credit-fueled housing and consumption were the principal drivers of the U.S. economy. One of the challenges of the post-bubble economy is to find new sources of growth. Logically, business investment and an improvement in net exports would take up the slack left by household de-levering and the retrenchment in housing. But as noted already businesses have had little reason to add capacity or hire new workers given the weak and uncertain demand outlook, and the structure of the larger world economy thus far has not conduced to trade adjustment.

\section{Part III: Why Conventional (and Unconventional) Policy Has Not Worked}

Given the nature and magnitude of the problem as we have just laid it out, it is understandable that the conventional policy responses of monetary reflation and fiscal demand stimulation, particularly when temporary, general, and largely tax-based in character, would fall short. These measures simply are not responsive to the nature of the problem as we have just laid it out.

The limits of monetary reflation: Monetary reflation was the principal policy focus in the early stages of the crisis. This was sensible at the time inasmuch as it did serve to stabilize the financial system, as had to be done. But it has now reached the limits of its effectiveness in supporting economic growth. Effectively zero interest rates have helpfully reduced the debt-servicing burden, but they cannot prompt businesses to invest when consumer demand is weak and when global and domestic capacity are more than adequate to supply that which is demanded hence the oft-cited analogy to "pushing on a string" in a liquidity trap. What's needed more now is to pull on the string, as we describe below. 


\section{Quantitative Easing (QE) offers diminishing returns:}

We are concerned that the diminishing positive effect on equities wrought by $\mathrm{QE}$ efforts, which underwrites fleetingly positive wealth effects, is eventually more than offset by the cost of rising energy and commodity prices that it might induce through a wall of liquidity chasing assets and a weaker value of the US dollar. For those act as a net drag on economic growth and push up inflation in emerging and other economies. Excess liquidity produced by extraordinary monetary easing did not, unsurprisingly, per our diagnosis of the challenge we face, flow into investment in new capacity for which there is no demand, but rather into money substitutes - tradable commodities. While we expect QE to be a continuing part of policy as an offset to deflationary pressures, we anticipate that successive rounds of easing, if unaccompanied by the policies we prescribe below, will eventually only confirm expectations of protracted low growth and a Japanese-style U.S. yield curve. We do, as discussed further below, see benefit to more direct forms of credit easing tied to end users, as opposed to general QE aimed at stimulating intermediaries to lend. ${ }^{11}$

\section{Diffuse/indirect demand stimulation has limited effect: As}

noted above, the economy is now suffering a dramatic shortfall in global aggregate demand, relative to supply, stemming from the "triple threat" of post-bubble debtdelevering, rising inequality and under-employment, and the continued export of wage deflation from Asian and other trade-surplus economies. In a globalized economy with excess capacity and ongoing private sector de-levering, diffuse, as distinguished from concentrated, demand stimulation through tax cuts and income supports can have only limited effect. For indirect fiscal stimulus of this kind is either rationally hoarded in significant part by the individuals who receive it, or goes to pay down their overhanging debt, or leaks out of the economy to buy yet more cheap imports.

As suggested earlier, debt deflation amounts to a collective action problem; individually rational behavior renders tax cuts collectively ineffective. In these circumstances, temporary fiscal stimulus aimed only at diffuse, indirect demand stimulation via tax-cuts or income-support has little or no multiplier effect. As a consequence, the public debt burden increases faster than GDP, because the loss of revenue from the tax cuts is greater than the GDP it stimulates. The fact is that in a world of idle capacity and continued productivity growth, businesses can meet any current and medium-term demand without material pressure on wages or existing capacity. Under such conditions, seeking to encourage investment by stimulating general demand is extremely inefficient. We simply dig ourselves deeper into the liquidity trap.

\section{Trade adjustment is not yet available on a sufficient scale:}

There has been a modest improvement in net U.S. exports, and this of course has been somewhat helpful to the economic recovery. But the improvement is largely a temporary result of the dollar's decline - a decline that is now ending with the push towards competitive devaluation elsewhere as in the 1930 s and with the flocking of onceagain fearful global investors to "safe haven" dollardenominated investment assets. The recent modest boost in U.S. exports is also the temporary result in part of the very early stages of a domestic wage deflation that we now appear to be entering.

In a "normal" debt deflation, debtor economies that must de-lever can substitute external demand for reduced domestic demand. Trade adjustment is aided by a fall in that economy's currency relative to that of its main trading partners. This is how Sweden and Canada successfully worked off their credit bubbles and debt burdens in the 1990s. But this option is not available to the United States at this time for several reasons. One is that Europe and the United States can't both pursue trade adjustment simultaneously, and the Euro-zone seems poised to win the battle for the weaker currency. Another is that the United States is locked into a de facto "dollar zone" with China by virtue of China's continuing policy of pegging the yuan to the dollar. Since the London meeting of the G-20 in April 
2009, Beijing has not allowed its currency to appreciate against a basket of currencies, leaving it still undervalued by 25 percent according to some estimates. Finally, there is the reality that while demand is growing in the BRICs and other emerging economies, these economies are not yet anywhere near sufficient contributors to global aggregate demand as to put the United States into actual trade surplus, especially when we factor-in the large surpluses of the petro-dollar economies.

It is true that in principle emerging market demand will help but is certainly no answer for the near-to-medium term. Demand in China and other large emerging economies in particular may eventually help to drive global economic growth. But the transition to more balanced consumer-oriented societies will be uneven and will take years or decades, not months. And it could even be accompanied by periods of social, political and economic breakdown similar to those that Europe and the United States suffered in the last century, during their own "take-off" periods.

\section{Other Non-Solutions}

As signs that the economy has stalled and may be heading for a new recession have increased, an array of other ideas has risen to the surface. These range from the obviously non-sensical to ideas that sound plausible but are really blind allies.

Fiscal austerity. Among the most troubling is the idea of fiscal austerity. Under existing conditions of weak global demand, austerity would simply lead to a vicious circle of yet weaker demand, weaker investment, more unemployment, and still weaker demand, ad infinitum the familiar "downward spiral" of all "great" depressions wrought by the "paradox of thrift." This is especially true if austerity is pursued simultaneously in Europe and the United States, as now is in real danger of happening owing to European measures that are just as wrong-headed as now-voguish American ones. And if the emerging economies in Asia and elsewhere begin to experience slower growth rates, as is now being projected, U.S. austerity will do yet more damage.

Deliberate monetary inflation: Also proposed by some, deliberate inflation is not a satisfactory option either, even if it be less dramatically misconceived than is austerity. Higher inflation would admittedly help reduce the burden of outstanding debt, but it would also be difficult, if not

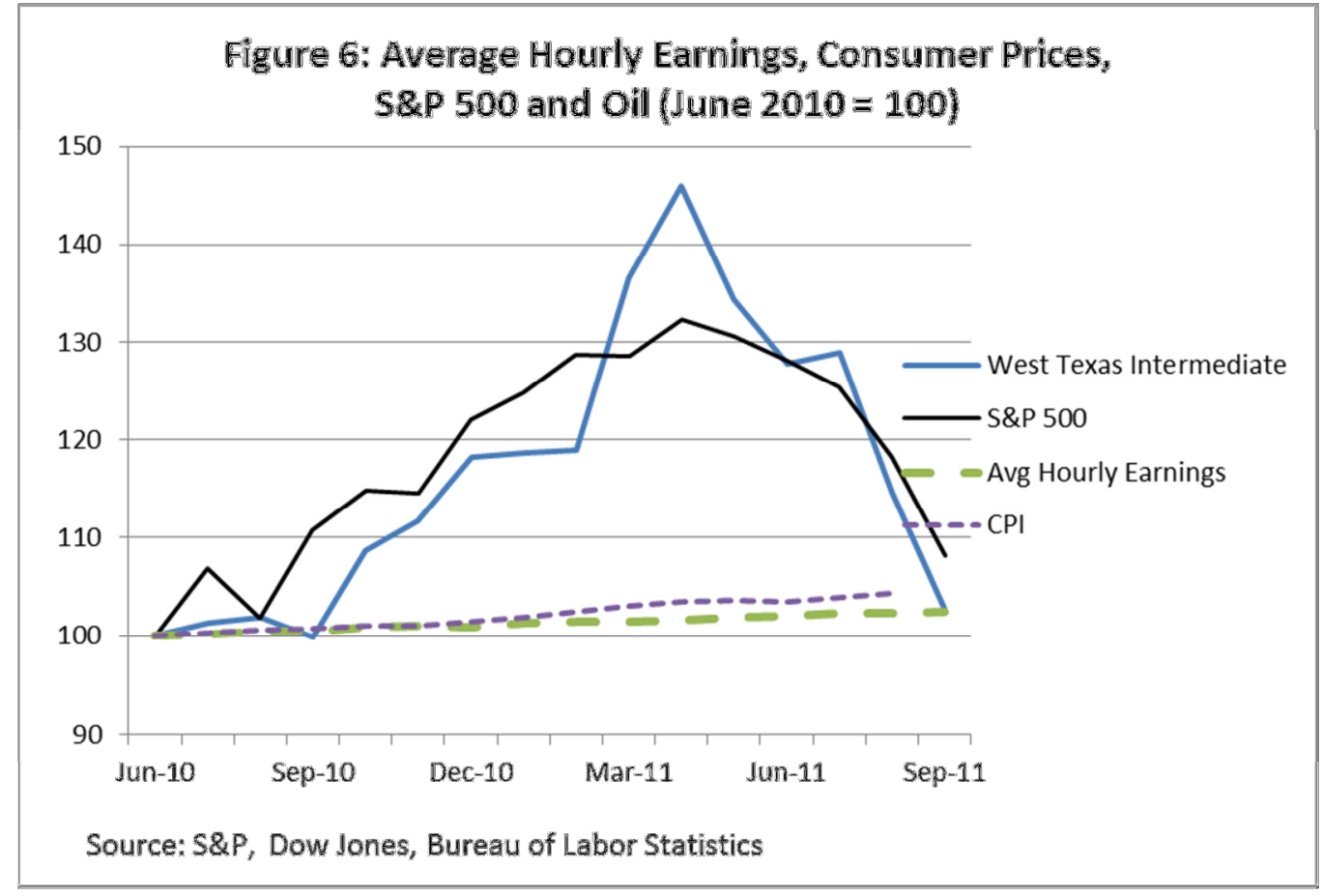

downright impossible, to generate wage inflation sufficient to match asset- and consumer-price inflation, given the magnitude of our current excess reserve of labor both within and without our borders. We saw precisely that outcome while QE2 was underway. And without wage inflation, price inflation will actually add to the economy's woes, all while being, as a practical matter, in any event unsustainable. See Figure 6, on the previous page. 


\section{A Grand Bargain of short-term stimulus combined with}

long-term fiscal consolidation: This has emerged as the responsible centrist position in policy and media circles in DC - it is, in fact, the essence of the President Obama's recent proposal (see below). On the face of it, it seems eminently sensible but again it does not fit economic realities. The main problem with this proposal is that the short-term stimulus envisioned by those pushing the idea looks much too much like the three previous stimulus efforts but smaller. It is too temporary, too focused on short-term tax relief and consumer support, and too misdirected to provide the economy more than a modest and temporary boost, as opposed to the bridge to long-term restructuring and recovery that the U.S. economy requires.

This, again, is a solution designed for a typical business cycle downturn. But as we have shown we are facing a much more

serious challenge of a multi-year de-levering process. In keeping with the analysis of other de-levering studies, we estimate that it will take at least another five to seven years for households to repair their balance sheets, for unemployment and underemployment to return to normal levels, and for balance to be restored in global demand and supply given the problems we see in Europe and given the length of times it takes for emerging markets to develop domestic demand.

Take, for example, the household debt overhang. As noted earlier and in Figure 7 below, total household debt to GDP exploded from approximately 65 percent in 1996 before the bubble to 99 percent in 2009, and household debt as a percentage of disposable income increased from 88 percent in 1996 to 130 percent in 2007. By contrast, household debt to GDP hovered between 40 and 50 percent for much of the postwar period, and household debt to disposable income was below 60 percent. Even if the household to GDP only reverts back to its early bubble average of 70 percent, households would need to eliminate nearly $\$ 2.8$ trillion in outstanding household debt. At the present pace of de-levering, that would take at least four years.

\section{Figure 7: Household Debt to GDP}

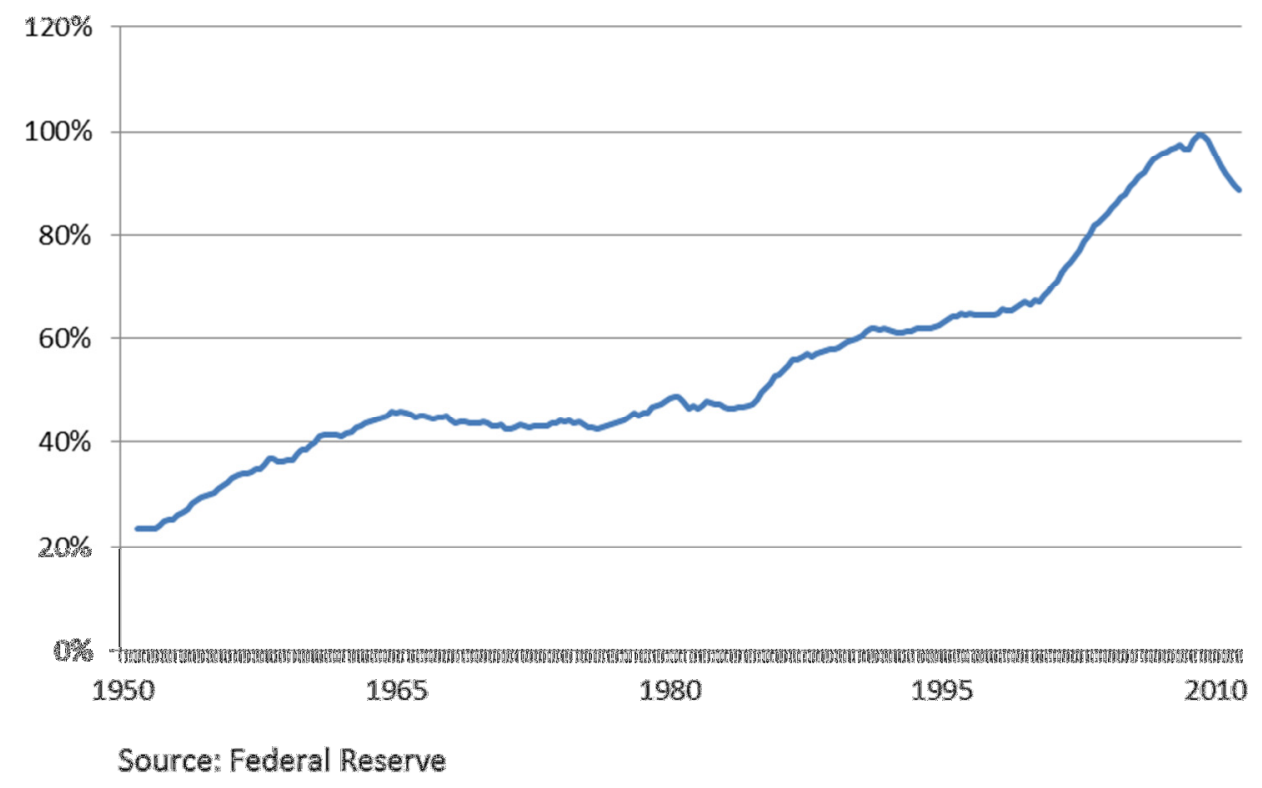

\section{Part IV: Criteria for a Workable Post- Bubble Recovery Plan}

Current economic conditions call for a much different kind of recovery program than those proposed or attempted thus far - one that is more sustained, more substantial, more concentrated, and more strategically aimed at creating new sources of growth. That was what we did as a nation during the sole precedent to the present period - the debt-deflation years of the 1930s. Rather than lurching from one futile mini-stimulus and quantitative easing to another, we must build consensus around a five-to-seven-year plan that matches the likely duration of the de-levering with which we now live, as well as that of the time it will take for emerging markets to transition to patterns of economic growth driven by domestic demand rather than exports. We believe there are three basic criteria that should guide 
the construction of such a longer duration recovery program.

One: Concentrated demand: A workable recovery plan must fill the gaping demand hole currently opened by consumer/private sector de-levering and widened even further by consequent underemployment. It must do so in a way that both creates reliable jobs and contributes to America's future productive capacity and investment needs. That means sustained and strategically concentrated public investment, not temporary, diffused would-be consumer demand stimulation. The overriding goal is, first, to offset the contractionary effects of the controlled liquidation now underway in many sectors of the economy with new sources of economic growth -infrastructure investment, development of America's abundant energy sources, and new technological development, in particular. The goal also is, second, to provide the now sorely needed certainty that demand will be there for the long haul, so that businesses have the confidence needed to invest, rather than save their retained earnings, and add to their workforces again. ${ }^{12}$

Two: Debt-overhang reduction: A workable recovery plan must facilitate and expedite the ongoing de-levering of private sector individuals and firms by both reducing the relative debt burden and boosting aggregate wages and incomes through greater job creation. ${ }^{13}$ That means a new program of debt restructuring, refinancing, and in some cases relief - particularly in connection with household mortgages and commercial real estate - that will require creditors to recognize losses and recapitalize. This stands in marked contrast to the present policies of (a) general monetary reflation, which tends in the end to inflate the wrong asset prices - in particular, those of commodities in the absence of corresponding wage growth; and (b) regulatory forbearance, which simply creates further uncertainty and undercapitalized “zombie banks.”

Three: Global rebalancing: A workable recovery plan must begin at long last to address the deep structural deficiencies and imbalances that have built up in the U.S. and global economies over the past several decades. Our recent real estate and financial asset-price bubbles were, in principal measure, the joint product of these long-developing domestic and global imbalances. Those imbalances included (a) a warped financial architecture that mis-priced risk and channeled excess savings into housing and other non-productive investments; (b) global imbalances between high-savings producer oriented economies like Germany and China and low-savings consumer-oriented economies like the United States and the United Kingdom; (c) imbalances between global labor and capital that resulted in weak wage growth; and (d) under-developed current energy sources and weak investment in new energy sources, which resulted in the transfer of wealth from working Americans to petro-dollar economies.

All in all, a robust recovery program must create a 5-7 year bridge to a new, more balanced domestic and global economy. This is the minimum time necessary for the private sector to reduce its debt overhang, for excess labor and capital to begin to rebalance, and for large emerging economies to take over more of the burden of providing demand for the world economy.

Such a program will inevitably raise concerns about the federal government assuming additional financial burdens. But this is a short-sighted view. In fact, the program we are suggesting should be seen as taking advantage of a historically unique opportunity to put idle capital and labor to rebuild our economy at an extremely low cost and with potentially high returns given the slack in the economy. We believe many - particularly those who now call for government austerity - are unmindful of this unique opportunity, hence unmindful of the opportunity-cost that their prescriptions would impose. Capital costs are now at historic lows - even for the longest of bond maturities, and labor is in abundant supply, precisely because of the present slump. It will never be less expensive than it is now to put these growth sources to work - indeed, back to productive work. It also will never be cheaper, as we now approach the zero lower bound in interest rates across the 
developed world, for the United States and other developed nations to finance their redevelopment efforts. That is especially true of the United States, thanks to the special privilege that it enjoys by virtue of the dollar remaining, for now, the world's primary reserve asset.

The fact is that trillions of dollars are lying idle because the private sector has no reason to invest given the sustained weak demand outlook. At this point, investors are quite content to sit on substantial reserves rather than take risk or even to "reach for yield" in longer term investments of any credit quality. Even the spreads between short and long term U.S. treasury yields indicate that investors are happier earning basically nothing and having complete flexibility with money. In other words, they are hoarding liquidity in the face of uncertainty over future investment prospects. Hence it falls to public sector to put this capital to work. Governments are the only entities that can extract economic utility from the present capital glut. Governments are not subject to the imperative to generate equity returns since they are not profit-generators. But they can create value by using this excess capital to make investments in the economic future that will redound to everyone's benefit.

\section{Part V: The Way Forward in Detail: A Three-Part Recovery Plan}

As noted above, we believe that the best way to satisfy the criteria just outlined is through a three-pillared program of (1) robust public infrastructure investment that stimulates sustained employment-generating demand growth and that renders the macro-economy more productive and efficient; (2) comprehensive debt restructuring and financial reform that trim debilitating and growth-impeding debt overhang; and (3) large-scale global rebalancing that restores the world economy to a healthy pattern of economic growth and that facilitates American debt-delevering.

\section{Pillar 1}

\author{
A \$1.2 Trillion, Five-Year Public Investment Program \\ targeting high return investment in energy, transportation,
}

education, research-and-technology-development, and water-treatment infrastructure.

U.S. public infrastructure is in shambles and is rapidly deteriorating. The American Society of Civil Engineers estimates that the United States must spend \$2.2 trillion on infrastructure over the next five years to meet America's most basic infrastructure needs but that less than half that is currently budgeted, leaving an approximately $\$ 1.2$ trillion shortfall. A multi-year program designed to close that infrastructure deficit would not only help fill the demand hole but make the economy more productive and efficient in the long-term. Indeed, long-term investment in public infrastructure is the best way simultaneously to create jobs, crowd in private investment, make the economy more productive, and generate a multiplier of growth in other sectors of the economy.

Committing ourselves to a five-year \$1.2 trillion infrastructure investment program would go a long way to filling the demand hole in the economy created by debt delevering and high unemployment. It is estimated that every $\$ 1$ billion of public infrastructure investment generates, by the most conservative estimates, 23,000 well-paying jobs. Over the course of five years, we estimate that this program will create over 5.52 million jobs in each year of the program. Beyond this, it is important to note that infrastructure investment has a healthy multiplier effect throughout the economy. The CBO estimates that every dollar of infrastructure spending generates on average a $\$ 1.6$ increase in GDP. Some critical transportation and energy projects have even larger multiplier effects.

A robust program of infrastructure investment is also critical to restoring American competitiveness. According to a recent report by the World Economic Forum, we have fallen to $16^{\text {th }}$ place worldwide in the quality of infrastructure. ${ }^{14}$ A variety of infrastructure bottleneckstraffic choked roads, clogged-up ports, an antiquated air transportation system, and an unreliable electrical gridare costing our economy billions in lost income and 
growth. The Department of Transportation, for example, reports that freight bottlenecks cost the American economy $\$ 200$ billion a year-the equivalent of more than 1 percent of GDP. And the Federal Aviation Administration estimates that air traffic delays cost the economy \$32.9 billion a year. Perhaps even more worrying, there is growing evidence that uncertainties about the future reliability of our energy, water and transportation systems are creating obstacles to investment in some parts of the country and thus impeding new business investment.

Our economic peers and competitors are not unmindful of how quality public infrastructure facilitates private economic activity. China, for example, invests 9 percent of GDP per annum in public infrastructure, while we spend well less than 3 percent. As an earlier New America Foundation report noted, "In today's globalized economy, public infrastructure is more critical than ever to the competitiveness of the traded sectors of the economy. Public infrastructure investment makes private investment more efficient and more competitive globally by eliminating many of the bottlenecks mentioned above and by lowering the cost of transportation, electricity, and other core business expenses. Infrastructure investment is also essential to the development of new growth industries. In fact, many of the new growth sectors of the economy in energy and clean technology require major infrastructure improvements or new public infrastructure."

If the infrastructure deficit is ignored, it is only likely to get worse. Deteriorating infrastructure is subject to "costacceleration" where repair or replacement costs grow with time. A project that costs $\$ 5$ or 6 million to repair now may cost upwards of \$30 million to repair merely two years from now. ${ }^{15}$ Since most of these projects will need to be undertaken at some point, the question is literally not whether but when. Not to undertake them now would be to leave money on the table. Combine this consideration with the fact that labor and capital may never be noticeably cheaper than they are now and with the need to generate job creation and economic growth, then it becomes immediately apparent not to undertake massive public infrastructure investment now would be nothing short of financially irrational.

In light of the overwhelming need, on the one hand, and unparalleled opportunity, on the other, to restore both short-term and longer-term economic health through productive real public infrastructure investment, we propose the following program:

- A five-year public investment program in transportation, energy, communications, and water infrastructure; science and technology research; and human capital enhancement, which can be extended as needed.

- Target: \$1.2 trillion of additional public/private investment, resulting in the creation of an additional over 5.52 million jobs in each year of the program - directly, through the projects themselves, and indirectly, through the multiplier effect on other sectors of the economy.

- An emphasis on high-return strategic investments in energy, transportation, and communications to eliminate economic bottlenecks and restore productivity, complemented by labor-intensive investments in energy efficiency (retrofitting homes, offices, and pubic buildings) to maximize job creation.

- Establishment of a national infrastructure bank, the expanded use of existing public-purpose credit facilities, and the use of existing bond issuance authority, so as to maximize investment at the lowest possible cost to the taxpayer.

- Tapping private capital markets additionally through issuance of Reconstruction Bonds by an agency established to fund and operate major public works program constructed under the 
auspices of the Directorate of Civil Works of the U.S. Army Corps of Engineers (USACE) mostly through private sector contracting.

- Offering multinational businesses the opportunity to fully repatriate profits from abroad with no additional taxation, on a dollar for dollar basis for all investments in the above mentioned Reconstruction Bonds.

- Expansion of the Directorate of Civil Works of the USACE to act as project manager and general contractor of last resort in order to limit private sector overbidding and labor union dominance "build at a fair price, or we will build it ourselves. ${ }^{{ }^{16}}$ We also advocate the streamlining and the speeding up of the environmental impact review process and the suspension of Davis-Bacon era prevailing wage laws that currently impact federally sponsored construction projects and those of many states as well.

The proposed five-year program would produce the following returns on investment:

- An average increase in national income (GDP) of 7 percent annualized during each quarter in which the program is employing incremental workers: ${ }^{17}$

- an additional over 5.52 million jobs in each year of the five-year program, many of which would result in new skills training for lesser skilled workers;

- productivity and efficiency gains as completed projects reduce travel times as well as cost and frequency of remedial maintenance, and result in increased flow rates for people, products, power and information throughout the economy;

- substantially lower private and public costs and a higher quality of life including less pollution, lower energy costs, faster commute times, fewer traffic casualties, cleaner drinking water, and better educational facilities;

- the expansion of public capital (assets) and higher future tax revenues because of the economy's increased economic growth potential;

- reduction of the long-term federal government deficit because of higher tax revenues and lower government income-support program costs that result from higher economic growth and lower unemployment.

\section{Pillar 2}

\section{Debt Restructuring and Regulatory Capital Loss Absorption}

The resolution of trillions of dollars of impaired debt in the developed world is a problem at least as nettlesome as that of addressing unemployment and inadequate demand. Indeed, this massive debt overhang must be addressed in order to be able to make sustained progress on lowering unemployment and boosting demand.

There are, as a practical matter, only four solutions to an unsustainable debt problem:

One. Strong economic growth can make debt sustainable; but growth in advanced economies will remain anemic as long as there is a need to de-lever.

Two. Net debt can be reduced by increasing savings; but Keynes' paradox of thrift suggests that if both consumers and governments simultaneously spend less and save more, the resulting recession and contraction of GDP will simply render the original debt unsustainable again. A macroeconomy cannot "save its way out of recession."

Three. Unexpected inflation can wipe out the real value of private and public debts and avoid debt deflation. But 
inflation can also result in substantial collateral damage and, in any case, is nearly impossible to engineer when an economy is in a deflationary liquidity trap as we are now in.

Four. If an economy cannot (1) grow, (2) save, or (3) inflate itself out of an excessive debt problem, then the only solution remaining is (4) debt restructuring: reduction and/or conversion into equity. This is widely recognized to be true for businesses but it is just as true for governments, households, banks, and other financial institutions.

In order to avoid a sustained period of debt deflation because of a massive debt overhang, it is imperative to trimback, refinance, and restructure the overhang itself. That is the only way to avoid multiple decades of debt-deflationary slump as Japan has endured since the early 1990 os. Moreover, in cases involving a credit-fueled asset price bubble that was no more foreseen by debtors than by creditors, then equitable burden-sharing is as fair as it is necessary.

A creditor's interest is in maximizing recovery on otherwise not-fully-collectible loans. In other words, banks and other financial institutions that hold mortgage and other impaired loans would like to maximize the net present values of loans that cannot fully perform. Debtors, for their part, seek to eliminate as much of the burden as possible. The problem, however, is that multiple creditors of individual debtors notoriously face collective action problems of their own when it comes to designing valuemaximizing work-out arrangements that would benefit all. That is precisely why the United States, like other developed nations, has a Bankruptcy Code. Unfortunately, the U.S. Bankruptcy Code is weak where real estate is concerned: mortgaged primary residences are generally excluded from bankruptcy courts' consideration and intervention. Recent proposals in Congress to amend the Bankruptcy Code accordingly warrant careful consideration. While that decision is pending, however, we offer complementary and much more streamlined measures of our own.
Regardless of the relative benefit of debtor/creditor settlement and how that benefit might be most efficiently obtained, one overriding fact remains. Creditors must recognize some loss of capital connected to restructurings. But some banks and other financial institutions may not have adequately provided for that eventuality and/or for the amount of the loss involved. This is the case for financial institutions in the United States and Europe that hold loan portfolio assets involving households, commercial real estate owners, and certain sovereign nations that are unable to repay or even service their debts given economic conditions over the foreseeable future.

What is more, the magnitude of our present mortgage debt crisis is such that the lenders, especially regulated institutions, frequently shy away from seeking to maximize overall recoveries on troubled loans through principal reductions. This is because of concerns with (a) the impact on current capitalization, and (b) the putative moral hazard of "rewarding" over-levered borrowers with loan principal reductions.

Where neither creditors nor debtors foresaw the burst of the housing bubble, however, it is not clear that there is any more moral hazard on the part of borrowers that would be created by restructuring, than there is on the part of lenders that would result from the failure to restructure. Moreover, we are in any event now at a point in the debt crisis where it is clear that actions to work with borrowers on restructuring and debt forgiveness - including households in the United States and sovereigns in the Euro-zone - represent the only effective means of maximizing overall recoveries. That is because the debt overhang itself prevents an economic recovery that would be needed for debtors to be able to repay their loans. Over-indebtedness relative to asset values and incomes is inherently deflationary, as it dramatically restricts consumer demand. It is the very essence of a debtdeflationary recession or depression such as that we are now experiencing. 
Regrettably, programs attempted thus far to address the problem - notably the Home Affordable Modification Program (HAMP) and the Home Affordable Refinance Program (HARP) - have proved both inadequate and needlessly costly.

One reason is that they have focused principally on rescheduling and reducing interest, and not on principalreduction. A quarter of homes are now "underwater" - i.e., are market-valued at less than the debt on their mortgages. One highly respected industry expert projects that, if nothing is done to ameliorate the present situation, roughly 8.3 to 10.4 million additional homeowners will likely default and lose their homes - out of the 55 million of mortgage loans currently outstanding. ${ }^{18}$ This in turn will create additional downward pressure on the housing market, thereby putting in jeopardy even more mortgages. We therefore cannot afford to ignore principal-reduction as a critically important option.

Another problem with approaches attempted thus far is that they have relied heavily on monetary incentives provided by the government in order to induce creditors to act in their own interest. This has made the programs very cost ineffective.

Finally, the "one size fits all" nature of the programs attempted thus far renders them unnecessarily blunt instruments that assist only the relative few debtors whose difficulties they actually "fit." A more successful approach to the mortgage debt overhang and attendant mortgage market slump will have to be more nuanced and more granular than what has been attempted thus far.

In the Appendix to this paper, we lay out a highly structured and appropriately granular approach to getting the U.S. household debt overhang under control. The solution addresses the distinct issues facing each of the two parties to any debt contract - borrowers and lenders.
With regard to borrowers, we offer three independent solutions, addressing the three principal circumstances in which the vast majority of borrowers find themselves today:

1) Mortgages that are not under water and whose mortgagors face only temporary, recession-caused difficulties in remaining current. For this subclass, bridge loan assistance offers an adequate solution. ${ }^{19}$

2) Mortgages that are under water and whose mortgagors will be able - and for whom it will indeed be financially rational - to pay off their debts only insofar principal is reduced so as to bring debt price and home value into closer alignment. For this subclass, a carefully crafted reduction plan akin to what we suggest in the Appendix will be necessary.

3) Mortgages whose mortgagees in ordinary circumstances would not have been up to the task of purchasing rather than renting homes - the proverbial "marginal" borrowers who were able to obtain "subprime" mortgage loans during the bubble years solely because they were bubble years, during which time credit was unsustainably cheap and available to all. For this subclass, we prescribe a carefully crafted "rent to start-over" program that on the one hand prevents a flood of additional foreclosed homes onto the liquidation market and puts in place lease contracts more appropriate to these beneficiaries, while on the other hand also offers an option to purchase insofar as some such beneficiaries might be able to restructure their financial lives during the period of their tenancy.

Regardless of the degree of regulatory pressure brought upon financial institutions to resolve distressed and undercollateralized loans, there is a risk that some institutions will become de-capitalized to the point that current capital requirements prescribe the impossible: namely, that they 
raise substantial equity during a period like the present, in which the equity markets question whether these institutions will even remain under the control of their shareholders.

Furthermore, one of the vestigial remnants of bubble is some $\$ 904$ billion of home equity lines of credit (HELOCs) as of Q2 2011 - about 75 percent of which are secured by mostly under- and un-collateralized second liens. Because many homeowners remain current on their HELOC - even while becoming delinquent on underlying first mortgages an unforeseen and un-natural condition exists in which senior lenders are forced into a Hobson's choice of either (a) offering a mortgage principal reduction that, without a commensurate reduction in the related HELOC, would enrich a third-party subordinate lienholder but not assist the borrower, or (b) proceeding with a foreclosure action that, while wiping out the HELOC, would almost certainly result in a much lower recovery of principal than that which would result from the aforementioned principal modification. This, of course, is no choice at all.

For these reasons, the Appendix also offers a "reality-check" in the form of (a) proposals enabling institutions to recognize losses, arising from voluntary actions to write off loan principal, over an extended period of time; and (b) a new regulatory regime aimed at setting straight the currently corrupted relationship between unaffiliated senior loan and HELOC lenders.

The reader, before digging into the Appendix, should note that all of our proposals were drafted with an eye towards minimizing possible moral hazard. That risk is undeniably present, in potential at least, in both (a) any offer of settlement of a debt for less than the amount owed and (b) any regulatory forbearance with respect to delayed recognition of losses. We have therefore carefully crafted our proposals to avoid the prospect of any "free lunch," while also weighing the risk of moral hazard against the relative macroeconomic benefits and costs of debt reduction. Under our proposals, the parties to the suggested remediation must work for whatever benefit they are afforded - either by foregoing certain other rights or by agreeing to a conservative regime of financial, legal, and/or accounting requirements.

\section{Pillar 3}

Global Rebalancing - A New G-20 Commitment to Currency Realignment, Domestic Demand Growth and Reduction of Current Account Surpluses, and IMF and G20 coordinated recycling of East Asian and Petro-dollar Surpluses to Support Economic Recovery in Europe and the Middle East

No domestic solutions to the problems of debt deflation can succeed without complementary global reforms. As we argued earlier, the imbalances in the U.S. economy that resulted in the housing and credit bubble were the domestic manifestation of imbalances in the global economy between surplus and deficit economies. Also, as noted earlier, the present challenge of successful debt delevering in the United States depends in part upon successful global rebalancing.

The outlines of what a coordinated global rebalancing would entail are well known and have been part of the international economic orthodoxy for a number of years. In the broadest terms, large deficit economies, like the United States, the United Kingdom, and the peripheral European economies, must increase savings and reduce their deficits and debt levels by increasing taxes and enacting spending cuts. In turn, large surplus economies-China, Germany, Japan, and the petro-dollar economies-must take up the slack by expanding domestic demand or, in the case of the the petro-dollar states, recycling their surpluses in such a way as to stimulate demand in other economies. In the case of China, that means letting its currency appreciate, allowing wages to rise, and putting in place a social safety net to reduce precautionary savings. 
While correct in theory, global rebalancing in practice will require a more nuanced and multi-speed approach that is properly sequenced. Germany will have its hands full with its own rebalancing challenges in the Euro-zone, and Japan has its own problems with one foot in the debtor side of the imbalance with an estimated government debt to GDP ratio of more than 220 percent. As important, given the larger imbalance between supply and demand in the world economy, it would be deflationary for the United States to move too quickly toward fiscal consolidation in the short to medium term, as this would push the U.S. and world economies into recession and actually increase the debt overhang. First priority must be given to correct the imbalance between supply and demand by boosting demand.

That is why in the case of the United States we envision a two-phase rebalancing process. The main goal of the first phase of five to seven years is for the United States to shift demand from government-supported personal consumption to public investment and more direct job creation. This will allow the household sector time to delever and for the tradable sector to strengthen its competitive position while giving the Euro-zone time to work its way out of its sovereign debt and banking problems and time for China and Asian export economies to restructure their economies to be less dependent on exports. And perhaps most important of all, this will allow the world economy time to work off its excess of labor, capital, and productive capacity.

It would also give time for the G-20 economies to come to some understanding of the kind of more far-reaching global reforms needed to prevent any re-emergence of global imbalances in the future. The second phase of global rebalancing would then entail not just the successful completion of the debt-delevering and rebalancing in the United States and the Euro-zone but also the implementation of these longer term global reforms. This means essentially a new Bretton Woods arrangement that provides for more automatic currency adjustment, for the regulation of global capital flows, and for a collective lender and consumer of last resort that is no longer dependent on the United States.

In the interim, it is important that the United States and the other G-20 economies make progress on the agenda of more urgent tasks of global rebalancing. In addition to delevering of the private sector in the United States, this agenda should include international support for the resolution of the Euro-zone debt crisis, the transition of China and other Asian export economies to more domesticdemand driven economic growth, and a world recovery fund to increase the resources of the $\mathrm{G}-20$ to assist deficit economies in Europe and to support recovery in the Middle East as well as other parts of the developing world.

\section{Euro-zone Rebalancing}

In the short term, the successful resolution of the European debt crisis is essential to avoiding a new global recession. Over the slightly longer term, how the Euro-zone rebalances - whether by austerity or by successful reflation and restructuring-will dramatically affect how successful the United States will be with its own economic rebalancing. If Europe persists with its current austerity course, it will make U.S. debt de-levering that much more difficult. Thus, the United States-indeed the entire world economy-has an enormous stake in the course of economic policy in Europe.

The key, of course, is the position of Germany and its willingness to bear the burden of rebalancing and debt restructuring. The Euro-zone is a mini-global economy with its own imbalances between the core surplus economies of Germany, Austria, and the Netherlands and the deficit economies of the "periphery"-Portugal, Ireland, Italy, Spain, and Greece. Ideally, Germany and other core surplus economies should pursue more expansionary policies while the peripheral deficit economies bring their deficits and debt levels under control. 
But the economic philosophy of fiscal rectitude and sound money is deeply embedded into the German political economy, and Germany has resisted not only the kind of more expansionary measures in its own economy that would facilitate Euro-zone rebalancing but also some of the Euro-zone level initiatives that are needed to resolve the European debt crisis. As is well known, the Euro-zone is struggling to pursue the actions it needs to undertake to avoid financial and economic contagion-whether it be organizing an orderly Greek default, assembling a financial stability fund of sufficient size, or recapitalizing and guaranteeing its banks-because it does not have the necessary economic government institutions needed to act decisively and quickly enough to calm the markets.

Up to this point, the United States and other G-20 governments have largely treated this as Europe's problem in part because Europe should have sufficient resources on its own to handle the restructuring of European debt. But given the enormous stakes, it is time for the G-20 and the International Monetary Fund to step up their involvement. The Federal Reserve and other world central banks have already been involved in providing some support through the extension of swap lines and other measures, and the IMF has committed some money to the Greek adjustment program. But bolder measures are now needed.

The key question is how to increase the resources of the European Financial Stability Facility (EFSF). Several months ago, the Euro-zone governments did agree to expand the EFSF to E440 billion but this is widely seen as too little and in any case requires the approval of all 17 national parliaments. It is clear that the Euro-zone needs the help and involvement of the larger G-20 to assemble the resources needed to reassure the markets and restore confidence in Euro-zone growth. For this reason, we recommend that the IMF and G-20 move quickly to put together a larger World Economic Recovery Fund described in greater detail below to supplement the EFSF. China, Brazil, South Korea, Saudi Arabia, and other G-20 countries would agree to committee funds to the World
Economic Recovery Fund, which could then backstop and increase the resources of the EFSF, in return for Europe to relinquish some of its power and influence within the IMF and World Bank.

\section{China, Emerging Asia, and Global Rebalancing} If Germany is the key to Euro-zone rebalancing, the key to global rebalancing is China in part because of its large stock of nearly $\$ 3.2$ trillion in foreign exchange reserves and in part because its surpluses have been at the root of the global savings glut. Indeed, by most measures, China, as its own leaders acknowledged, is the most unbalanced of all the major export oriented economies. Over the past decade, investment and savings in China have grown much faster than consumption. Consequently, China has unusually high gross national savings of nearly 50 percent of GDP, while consumption constitutes only 35 percent of the economy (the overall average of the other BRIC economies, Brazil, Russia, and India, is closer to 55 percent). And even though other economies in Asia are richer, the key to increasing world consumption demand is China, which by virtue of the size of its labor force increasingly sets wage levels for both developing countries and newly industrializing economies. An increase in Chinese wages and consumption would give other countries room to let their wages and consumption rise. Likewise, an appreciation of the yuan would give other BRIC economies like Brazil more room to let their currency increase in value to help control inflation without fearing of a flood of Chinese imports.

Many U.S. commentators have treated China's surplus primarily as a bilateral trade issue but it is also a matter of great importance for the world economy. It is not possible for an integrated global economy to function smoothly when the second largest and fastest growing economy consistently runs such large surpluses and consumes so little in relation to what it produces. For that reason, it is critical for the United States to do more to "multilateralize" this issue. Other economies have as much at stake in the 
successful rebalancing of the Chinese economy as does the United States.

In this connection, the United States should do more to help build an international consensus around the kind of reforms China should be encouraged to undertake over the next five years to facilitate global rebalancing. Many of these are already widely accepted within the Chinese leadership but they will need constant pressure-and not just from the United States-to implement them and not to fall back on old ways. In short, these reforms include the following:

- Develop a social safety net. China (as well as other BRIC nations) must put in place a stronger social safety net, one that provides for reasonable levels of basic retirement assistance for the aged, full healthcare for those no longer able to work, and substantial reductions in the amounts of personal spending on healthcare - which in China is now nearly 50 percent of national healthcare costs. Because China lacks a real safety net and does not have reliable public systems of health care, retirement, and education, Chinese workers are engaged in precautionary savings for these purposes. The best way to reduce this precautionary saving and augment demand would be to encourage China to do a better job of both providing education, health care, and retirement for its citizens.

- Increase wages and incomes. Precautionary savings by households is only part of the problem. The much larger part of the problem has been business sector savings, especially those of stateowned enterprises. The essence of China's investment and export model has been the transfer of income from the household sector to producers. One way to correct the imbalance that results would be for China to allow wages to grow faster than productivity to boost labor income and thus increase purchasing power for consumption goods. This would also have the benefit of reducing the race to the bottom in labor costs and would allow wages and incomes to grow in other economies.

- Pay out dividends and incomes. Another way of tackling excess business savings would be to encourage China to have its state-owned enterprises pay out profits in the form of dividends rather than having them recycled into the build-up of foreign exchange reserves. Using regulatory or tax policy, the Chinese government must aim to force much greater sharing of corporate earnings with shareholders - by both private companies and SOEs. Distributions from the latter would go a long way to funding some of the social welfare enhancements prescribed above, while distributions from the former will add significant consumer purchasing power to the demand side of the economy.

- $\quad$ Reduce export subsidies. Export subsidies to industry in China and other surplus nations constitute another significant drag on demand, and of course contribute directly to the oversupply problem in the world economy. Essentially for those reasons, they are also illegal under WTO treaty and case law. Export subsidies accordingly must be steadily and expeditiously phased out. Recognizing, as we do, that export subsidies must be ended in phased fashion, we recommend that subsidies to industries in which the developed nations are most directly competitive - high valueadded manufactures for the most part - be ended soonest, while subsidies to more labor-intensive industries then can be phased out more gradually. Ultimately, these measures will induce Chinese companies to improve general productivity and mechanization. The former will in turn redound to the benefit of the population of China, while the latter will provide attractive export opportunities 
for the high technology sectors of developed nations currently in deficit.

- Allow currency appreciation. These fiscal, social welfare, and trade policy measures must be complemented by appropriate financial sector reforms, in particular measures that allow for currencies to appreciate where appropriate. China and other emerging nations must steadily de-peg and permit open exchangeability of their currencies by 2020 . This too will have to be effected in phases that focus initially on removing currency controls - for which commitments from developed nations to eschew extraordinary monetary easing would be a critical requirement and finally on targeting annual appreciation targets before which central bank intervention would be permitted.

As noted earlier, the transition to a more balanced consumer-oriented society will take time. In the meantime, there are other ways that China can be more supportive of global economic growth. One option would be for the United States and China to more closely cooperate about the investment of China's substantial foreign exchange resources. Both economies have an interest in ensuring the stability of the U.S. bond and equity market, with China wanting to diversify some of its holdings away from Treasuries and toward other risk-free instruments and real assets, and with the United States wanting to retain control over its own monetary policy. One option would be for an understanding whereby China would over a period of time gradually reduce its Treasury holdings in favor of investment in the proposed U.S. Reconstruction Bonds, which would have higher yield.

A similar commitment could be made with respect to the "Eurobonds" that will eventually be necessitated by increased fiscal union within the EMU. Although controversial to both sides, direct investment into all but the most sensitive national security elements of industry - airlines, for example, would not be deemed such - must be substantially liberalized in both directions. And still other portions of the surplus should be redirected to support another piece of the bargain that we sketch below -the World Economic Recovery Fund, perhaps administered jointly by the IMF and the World Bank Group, to deal with balance-of-payments crises and support public works projects in developing economies.

\section{World Economic Recovery Fund}

The third initiative on our proposed global rebalancing involves the establishment of a World Economic Recovery Fund. The Fund would have three purposes. First, it would provide a vehicle for the recycling of global surpluses, particularly the large surpluses of oil-producing economies. In contrast to China and the other large exportoriented surplus economies that derive their surpluses from manufacturing, there are limits to how much resource-oriented surplus economies can and should do to stimulate domestic demand, especially since oil is an exhaustible asset. It would therefore be better for these economies to recycle some of their surpluses into productive, growth-enhancing investments in other economies.

Second, as noted earlier, the Fund would help supplement the resources of the EFSF and thus provide an organized vehicle for international assistance to the Euro-zone to aid its debt restructuring efforts. There have been at times talk of China buying Greek, Portuguese, and more recently Italian bonds because China has an interest in ensuring the health of one of its largest consumer markets. But this strategy would expose Chinese investors to unlimited risk. It would be better for China and other economies to devote resources to a collective vehicle that would reduce the risk while multiplying the impact of their investment.

Finally, the Fund would help replenish international development and international financial assistance resources that have been bled dry by first the world financial crisis and more recently by the IMF's 
commitment to European peripheral economies. While the European PIIGS grab all the headlines, there are a number of economies in need of adjustment support and development assistance from the Arab Spring economies of Egypt, Tunisia, and Libya to the still struggling economies of eastern Europe to many African nations. Many of these countries need immediate assistance, while still others may experience currency-related crises before the world economy is stabilized. The IMF, however, has only \$250 billion for managing national debt crises. That is a pittance in comparison to the rescue plans that the United States, Britain and other G-2o governments have set aside for the European debt crisis.

It is therefore imperative to shore up the resources of the IMF and the World Bank Group, and that could be accomplished with the establishment of the World Economic Recovery Fund, to be drawn upon and perhaps partly administered by the IMF, World Bank Group, and the Regional Development Banks - viz., the African Development Bank, Asian Development Bank, the InterAmerican Development Bank-as well as by the EFSF.

The establishment of the Recovery Fund would also strengthen the international economic and financial architecture that is necessary for the long-term management of the world economy. The Recovery Fund could be capitalized by nations whose current account surpluses have averaged 3 percent over the past five years or longer, would give us the ability to carry out a global macroeconomic stimulus program complementing national fiscal expansion. The IMF could tap the Fund to carry out currency stabilization programs and help countries manage balance-of-payments problems. The World Bank and Regional Development Banks could likewise use the fund to accelerate lending for job-creating public works and social investment in developing countries.

There is one other reform that requires noting here-and that relates to a more equitable sharing of power and influence within existing international economic institutions. The establishment of a World Economic Recovery Fund would be appropriate occasion to make further adjustment in global power-sharing. In return for their making outsize contributions to the Recovery Fund from which the IMF, the EFSF, the World Bank, and the Regional Development Banks would draw working capital, the United States and European nations would ensure commensurate governance roles for the current surplus nations in the running of the two Bretton Woods institutions - the IMF and the World Bank. Alternatively or in addition, these nations would have governance rights in the Recovery Fund itself commensurate to their contributions. ${ }^{20}$ The time has long since come for the changed role played by the emerging market nations in the world economy to find expression in the governance of the world's principal public economic institutions. And a governance role of this sort will in any event be a prerequisite to these nations' now playing a more contributory role as the world seeks means of recovery.

Ultimately, we believe that a more fundamental reform of the global economic architecture is called for. Clearly, we have seen over the last several decades the problems that develop when currencies do not steadily and automatically readjust so as to prevent long term current account surpluses or deficits, when a single nation's currency, in turn, serves as de facto global currency, reserve asset, and embodiment of global liquidity, and when there is no global institution able to provide credit globally on a scale sufficient to preempt rational self-insurance motives that result in foreign exchange hoarding by surplus nations. Our final recommendation, then, is that the United States and the G-20 should use this time to call and plan a new Bretton Woods conference.

In the meantime, it is critical that we move expeditiously on the more immediate parts of the global rebalancing agenda outlined here: the successful de-levering of the U.S. private sector, the resolution of the European debt crisis, the successful rebalancing of the Chinese economy, and the establishment of a World Economic Recovery Fund. 


\section{Conclusion}

We hope that we have succeeded in conveying both the unique magnitude, and the correspondingly unique urgency, of the problems with which the U.S. and global economies are now faced. This is no ordinary crisis, any more than the global supply shifts from which it ultimately stems have been any ordinary demographic developments. The sudden growth in global productive capacity relative to absorptive capacity, inklings of which appeared as early as the 1970 s and ' 80 s but the full force of which did not gather until the 1990s, has for the time being overwhelmed the capacity of the developed world to adjust.

Developed nations attempted to "buy time" for a while by resort to inexpensive credit - credit rendered all the more available by the global supply glut itself. But they did not structurally adjust quickly enough to head off that credit boom's inflation into a massive asset price bubble. Now that the variable prices of the assets that were artificially inflated by means of that credit have collapsed, all while the fixed debt that financed asset-purchases remains on the books, individuals, firms and even nation states find themselves faced with enormous debt overhang. For as long as they must hold back from spending in order to trim back that debt, they will be unable to provide effective demand adequate to the task of restoring economic growth and employment. And the longer that this remains so, the worse growth and employment conditions are apt to become.
This means that debt overhang must be reduced in part by restructuring and forgiveness, and that growth must be driven by sources other than consumers in debt-ridden developed nations. Smart investment by the U.S. government, financed by debt that is uniquely inexpensive to it by dint of the role that U.S. Treasuries and the dollar play in the global economy, must be one such substitute source of demand for the near future. In the slightly longer term, consumer demand, including import demand, from emerging market nations must be another such substitute. There simply is no other way.

For these reasons we have offered the foregoing detailed set of prescriptions for U.S. public infrastructure spending (Pillar 1), comprehensive debt-restructuring and, in some cases, forgiveness (Pillar 2), and both direct supply of demand and financing of additional demand on the part of current account surplus nations (Pillar 3). Future White Papers will recommend policies for the longer term - seven years out and beyond. But for the coming five to seven years, we are convinced that the foregoing prescriptions are both necessary and, we hope, sufficient. 


\section{THE WAY FORWARD}

\section{Appendix: Pillar 2: Debt Restructuring and Regulatory Capital Loss Absorption}

\section{A. Household Loan Bridge Loan Assistance, Debt Restructuring, and Rent-to-Start-Over Plans that Avoid Moral Hazard}

- Bridge Loan Assistance for Mortgagors in Temporary, Recession-Caused Payment Distress.

A sizable fraction of mortgagors now facing difficulty in remaining current on mortgage debt payments are distressed only temporarily, through no fault of their own, simply because of the underemployed in the current recession. Their mortgages are not underwater and their capacities to pay are not permanently impaired. Because most mortgagors are found to be in default after as little as 60 days' delinquency on mortgage payments, foreclosure on these borrowers' loans is needlessly - because avoidably - costly to lenders and tragic for borrowers. Furthermore, programs like HAMP and HARP, which cost the government many thousands of dollars per mortgage to administer and induce lenders to forgo portions of what they are owed, are much more expensive than necessary when employed on behalf of this class of mortgagors. All that these mortgagors need are temporary bridge loans; but of course under current economic conditions, private lenders are leery about "throwing good money after [perceivedly] bad."

Where private actors are unable to step in, as we have argued repeatedly above, is precisely where public actors are needed. Bridge loan assistance programs, which afford temporary payment assistance - typically for no more than 24 to 36 months - to mortgagors falling in this subclass have accordingly proved very effective and virtually cost-free in the few states that have tried them. A noteworthy case in point is Pennsylvania's Home Emergency Mortgage Assistance Program (HEMAP), on the books since 1983, which dramatically outperforms the federal HAMP and HARP programs. Other states, such as Connecticut, Delaware, and Nevada, have accordingly instituted counterpart programs of their own. One of U.S. has in turn drafted a counterpart statute for the State of New York and for the federal government. There is no reason not to adopt such a program at the national level for those current HAMP and HARP beneficiaries who require only temporary bridge loan assistance. Not to do so is near literally to leave money on the table.

A related way in which the U.S. economy is underutilizing the benefit of historically low interest rates takes the form of the unavailability of credit and loan refinancing to many exiting mortgage borrowers. Recession-induced fears on the part of private lenders, and even the now-governmentcontrolled Fannie Mae and Freddie Mac mortgage behemoths, prevent even existing mortgagors from refinancing because their loans are underwater - many severely so - against post-bubble home values. This may seem reasonable to many; after all, why would a lender offer in effect to cut interest payments on a loan that is so high-risk that a loss of principal is a near certainty? And, yes, many such borrowers - whether or not they refinance will eventually default rather than making payments on loan amounts they cannot recoup from their home's value. That is especially so if those values continue to decline. Furthermore, interest rates on many defaulted loans have already been modified by private sector lenders, even if a high percentage of such modifications have not been made permanent. 
Nevertheless, it does stand to reason that there should be some room for those who have not defaulted at all, but who owe more on their homes than lenders are willing to lend, to access the lower interest rates afforded to those who have defaulted - precisely in order to reduce their propensity to default in the first place. Yes, this would involve lenders' doing what they are generally not wont to do - offering to reduce loan payments on risky loans that are still paying. But considered in light of (a) the reduced expenses it will bring to affected households, which might in consequence actually increase their spending, and (b) the likelihood that it will reduce eventual defaults and foreclosures, it is a reasonable course of action. And that is so even though it targets a small number of people.

In particular, and notwithstanding the FHFA's view, as custodian of Fannie and Freddie, that general taxpayer interests supersede the potential benefits to the affected borrowers, we believe that the former-GSEs' offering more liberalized refinancing options to non-defaulting borrowers has merit. After all, the government already "owns the risk" on such loans. We are not as comfortable, however, with the suggestion that government has any role to play in the refinancing of loans held in the private sector. For that would involve taking on risk that properly rests with the original lenders. We believe, instead, that measures such as those set forth below, to encourage or even compel private lenders to workout imperiled loans using different means, will make for better policy.

\section{- Contingent Principal Reduction and Springing}

Repossession. In contrast to the subclass of mortgage debtors just considered, another subclass that faces distress that is occasioned not by temporary underemployment, but by dramatic imbalance between what their post-bubble homes are worth and what their pre-bubble promissory note debts require them to pay. For these mortgages, the only sustainable way to trim overhang and remove the drag from the primary and secondary mortgage markets will be to bring loan principal more closely into line with home value. Refinancing assistance of the sort noted just above can help too, and in that sense can usefully complement principal-reduction plans. But plans of the latter sort will nevertheless be necessary.

A host of recent data-accumulations and studies demonstrate that unless principal reductions meaningfully reduce loan amounts to a level at or quite near the value of underlying home collateral, and unless payments are affordable, loan modifications are ultimately more likely to fail than succeed. It is therefore critical that restructuring be sufficiently sizable to meet this challenge. One challenge to principal reductions to date, however, has been the perceived "moral hazard" entailed by partial debt forgiveness. We therefore prescribe a principal reduction plan that reduces this concern.

In order to minimize the potential for moral hazard that might be occasioned by affording borrowers "something for nothing," lender debt forgiveness should be coupled with equivalent cooperation from borrowers. Principal reduction will be required to be earned, in other words, in the form of proven loan performance on restructured mortgages loans. We therefore call them "Contingent" Principal-Reductions. To add an additional layer of prudence to the plan, we propose that contingent principal reduction plans should be limited to homes with mortgages that cumulatively - that is, with $1^{\text {st }}$ and $2^{\text {nd }}$ mortgages combined - exceed $110 \%$ of the value thereof. A ten percent "under water" measure is both simply administrable and appropriately in sync with what research shows to be realistic repayability. Moreover, refinancing assistance of the sort mentioned above in connection with the first subclass of distressed mortgagors can and should be offered to those who are less than ten percent under water.

Lender principal modification programs - whether government enhanced, as are HAMP, HARP and some similar programs, or otherwise - also should mandate a 12 month test period in order to answer the hitherto intractable empirical question as to who is likely actually to benefit from principal modification. The test period should employ loan payment schedules that reflect the assumed restructured mortgage terms prior to the granting of formal 
principal reduction. The latter then would become automatic once borrower performance proves forthcoming throughout the test period.

At the same time, borrowers participating in the proposed program should be required to execute confessions of judgment in favor of the most senior mortgage lender, enabling the lender to proceed with the repossession and liquidation of the home on an expedited basis, if more than two payments are missed by the borrower during the test period. The upshot of the symmetry here will be expedited determination of which loans' values truly will be maximized by principal-reduction, and expedited foreclosure on loans that cannot be thus salvaged.

An additional level of symmetrical resolution may involve a so-called "shared appreciation" structure pursuant to which creditors accepting principal value reduction of a mortgage would be issued a "warrant" that provides a capital gain to such creditors in the case that the home securing the mortgage is ultimately sold at a price in excess of the restructured mortgage amount (which excess would be shared between debtor and creditor until the point that the creditor is made whole). In this way the creditor becomes a partial equity holder in the home, thus partially converting the mortgage debt into equity.

\section{- Deed Surrender and Right to Rent. As noted}

above, a third subclass of borrowers will inevitably have suffered such extreme economic dislocation, and/or deflation in the value of their homes, that the degree of loan principal reduction required to stabilize loans and avoid enormous losses renders the foregoing Contingent Principal Reduction plan infeasible. Many, though presumably not all, members of this subclass own now solely by "virtue" of the recent mortgage loan credit bubble that brought theretofore marginal purchasers into the mortgage market - parties who would not under more normal economic conditions ever have so much as attempted to own rather than rent.
It is, nevertheless, valuable to the housing market to eliminate the addition to excess housing inventory of each incremental repossessed home, given the downward price pressure such excess exerts on the market. A thorough home mortgage market repair plan must accordingly seek out a middle way between outright principal reduction on the one hand, and simple foreclosure and liquidation on the other. That is of course fully in keeping with our hope, announced at the outset of laying out Pillar 2, to avoid "one size fits all" solutions and afford more granularity to the means by which we address the hitherto intractable mortgage market slump.

The way to address this third segment of the debt-overhang spectrum, then, we believe, involves shifting from mortgage to rental payments - including in some cases "rent to start-over" plans that assist those on the cusp between workable principal-reduction plans and outright rental plans. A variety of such plans currently are being proposed from many quarters. In order to choose from among them, or to improve any of them that is selected, a catalogue of desiderata will be helpful. We suggest that any workable plan will incorporate:

- Voluntary surrender of deeds by borrowers in cancellation of existing collateralized indebtedness, affording mortgagee the full benefit of mortgage indenture;

- A requirement that any borrower surrendering a deed be afforded a right to obtain a five year market rate lease for what was formerly his or her home, with all of the normal services provided by the new landlord, as would be typical for home leases in the borrower/tenant's region;

- A right on the part of the former lender, now landlord, to dispose of the home - either subject to the lease during the term thereof, or "free and clear" at the expiration of the term; and

- A right on the part of the former owner, now tenant, to reacquire the home - at fair market value 
- before the home is put up for sale free and clear of the lease. In effect, this amounts to a variation on the "statutory redemption right" that many states confer upon foreclosed mortgagors. In that sense what we propose is already familiar, but now adapted to a special national problem.

The foregoing alternative will require regulatory and legislative action to ensure its availability and compliance, but case law should be supportive of such a program from a constitutional point of view.

\section{B. Regulatory Capital Incentives and Relief Mechanisms}

Regardless of the degree of regulatory pressure brought upon regulated institutions to resolve distressed and undercollateralized loans, there is a risk that some institutions will become de-capitalized to the point that current capital requirements prescribe the impossible: namely, that they raise substantial equity during a period like the present, in which the equity markets question whether these institutions will even remain under the control of their shareholders.

\section{- Phased-in Recognition of Certain Loan Losses.}

Regulators should accordingly enable institutions to implement Special Asset Resolution Suspense Accounts (SARSA), into which would be booked all losses arising only from voluntary principal reductions offered by lenders to borrowers in the context of restructuring distressed residential and commercial real estate loans and unsecured consumer loans (credit cards). Amounts posted to the SARSA would, for the purpose of regulatory and GAAP accounting, be permitted to be amortized in equal amounts over a 7 year horizon, in lieu of being fully booked as a loss in the year incurred. In effect, this will constitute a straightforward counterpart to a strategy successfully employed by FSLIC in the late 1980 os with a view to incenting healthy thrift institutions into purchasing failed such institutions - the "regulatory goodwill" capital, amortized per the

"straightline method," that served to purchase cooperating institutions time in bringing themselves into compliance with the capital requirements of the day.

In the event that an institution does not have earnings in any particular quarter, equal to the amount of the SARSA amortization, the institution will be automatically required to raise additional capital in the amount up to the amount of the SARSA amortization or the institution's quarterly loss, whichever is less. SARSA treatment would not be available in the case of losses arising from the liquidation of collateral or other actions to collect on loans, but would be permitted in the case of deed in lieu and short-sale transactions. Again, the idea here is to afford a limitedpurpose buffer, where capital regulation is concerned, so as to eliminate inadvertently regulation-induced reluctance on the part of financial institutions to assist in the cleanup of currently cluttered mortgage markets.

- Dealing with HELOC Loan Roadblocks. Home Equity Lines of Credit (HELOCs) have presented a special, and indeed unique, challenge in the current crisis. This is by dint of their ubiquitous use as second mortgages behind already highly levered first mortgages during the housing bubble. At the end of Q2 2011, there were over \$904 billion in HELOCs and second lien term loans outstanding and - given the dramatic fall in housing prices since the time of origination - it is estimated that over half of outstanding HELOCs and most second liens are, for all intents and purposes, unsecured at this point.

Notwithstanding that unsecured status, in cases in which HELOCs are held by creditors other than the holder of the first mortgage loan, an unprecedented situation has developed: some borrowers are making payments on their smaller HELOC subordinate mortgages, while at the same time allowing their senior mortgage to default. Industry analysts surmise that this highly unnatural circumstance arises from borrowers' desire to maintain access to the 
revolving credit line associated with many HELOCs - which they require in the course of day to day living.

The upshot of this unique circumstance is that even in situations where first mortgagees wish to negotiate principal modifications with borrowers, they cannot do so without effectively rewarding the holders of HELOCs.

HELOC lenders that continue to receive payments are loath to agree to restructuring - even they are un-/undercollateralized - and this poses a significant obstruction blocking NPV-maximizing resolution of distressed residential mortgage loans. It poses yet another collective action challenge to measures that are literally in the interest of the totality of interested parties.

Regulators, and the executive branch more broadly, must accordingly take aggressive action to remove the HELOC roadblock as set forth below. These actions are aimed at either (a), preferably, restoring the normal relationship between senior and subordinate mortgage holders, or (b) if necessary, subjecting the holders of what are effectively valueless yet highly obstructive second liens to the surrender thereof:
- Second lien lenders that are subordinate to defaulted first mortgages would be required to establish additional reserves in an amount equal to that necessary to "cure" all defaults on the senior first mortgage - back interest, escrows, and penalties.

- Reserve provisions in respect of HELOCs secured by homes worth less than the amount of the first mortgage senior to the HELOC would also be increased to levels equivalent to those held in connection with fully unsecured debt, across the board.

- In connection with any HELOC loans held by lenders that continue to block co-equal modifications with first mortgage holders, the federal government, employing its eminent domain power to condemn property in the public interest, should take the subordinate mortgage lien only - not the mortgage note - for fair value. It is expected that fair value of a mortgage lien that is underwater will be nothing more than nominal. 


\section{Notes}

1 Monetary and, especially, fiscal stimulus are called for; but as we explain below, the forms they have taken thus far, predicated as they have been upon misdiagnosis of what ails us, have been misguided.

2 The is $54.6 \%$ if one subtracts employees who work part time - that is, between 1 and 34 hours per week - but want full time work. Note that all employment-to-population ratio comparisons with early periods require adjustment in light of steady growth in the number of women seeking employment over the past several decades. In earlier periods, the U.S. economy drew uncompensated benefits from unpaid women's labor which it does not today.

3 In Europe and the U.S., a period of this sort would likely be worse than its Japanese counterpart. For Japan has managed at least to maintain high employment.

4 While "Great Recession" has emerged as the moniker of choice in naming the past several years' difficulties, we note that many already have moved to the "Lesser Depression" label. As we demonstrate below, there are reasons for that.

5 As an investment banker/businessman, a professor of financial and international economic law, and an economist, we bring diverse perspectives to bear in what follows - picking and choosing from among all the tools of analysis and resolution that our unique backgrounds have enabled us to see and offer.

6 Including those of the U.S. during the 1930 s and Japan since the early 1990 .

7 In this connection we note with great interest the recent speech by World Bank Group President Robert B. Zoellick, "Beyond Aid" delivered September 14, 2011.

8 The rise in inequality stems from many factors additional to the effects wrought by trade with those countries abundant in low-skilled labor that are now joining the global economy. Among them are winner-take-all effects; less progressive or, in some cases, even regressive taxation; skills-biased technological change; rises in the cost of, and consequent reduction in, investments in human capital; and improving skills among even less skilled workers.

9 We define "credit bubbles" as sustained periods of growth in the domestic total debt to GDP ratio of $2 \%$ or more per annum. Note that Figure 3 goes back only to 1955 for reasons of data availability. The real estate and stock price bubbles of the $1920 \mathrm{~s}$ accordingly might - and presumably would - count as credit bubbles of the kind we have in mind, but we don't have the data to certify that likelihood. Credit bubbles are always accompanied by asset bubbles, of course, inasmuch as credit serves as an accelerant that further inflates asset prices during asset price hyperinflations. And credit-fueled asset price bubbles of this kind in the end prove systemically calamitous precisely by dint of the magnitude of debt overhang that they leave behind once they burst. But the converse - the proposition that all asset price bubbles are also credit bubbles - does not hold. And these noncredit-driven asset price bubbles - including that in the market for technology stocks in the late 1990s, for example - are accordingly not as systemically dangerous; they are more easily recovered from because they do not leave massive debt overhang in their wake. Accordingly not as systemically dangerous; they are more easily recovered from because they do not leave massive debt overhang in their wake.

10 Inasmuch as corresponding wage inflation is held down in many sectors by exogenous competition from labor in emerging nations.

11 Credit easing is a form of capital market disintermediation in which the risk/reward decisions commonly known as the "credit underwriting" and "pricing" functions of conventional primary debt capital sources - for the most part, banks - are taken by sources further up the capital provision food chain. Debt securitization, for example, is a classic form of bank disintermediation in which capital is provided by large accumulators of investment capital, insurance companies, pension funds, government related entities and private investment - principally hedge or private equity - funds make their own credit and pricing decisions - be that directly or, with recently problematic results, through proxies called "rating agencies" - about a package of loans to households or businesses. Credit easing at the monetary policy level moves credit and pricing decisions up to the lender of last resort, the money creating entity - typically a central bank - itself. There are a few areas in which credit easing could be a reasonable strategy today... and there will be a few more if credit conditions in the private sector actually worsen as they now 
threaten to do. The unwillingness of conventional credit intermediaries to lend, even against substantial down payments, to potential home buyers lacking in stellar credit histories - as many now do simply in owing to the disruption inherent in our present crisis itself - poses a damaging bottleneck in the credit markets that could be partly ameliorated through credit easing. Small and mid-sized businesses lack access to inventory and receivables lending at the low interest rates currently enjoyed by larger borrowers, potentially slowing recovery and re-employment. Accordingly, it may be helpful and prudent for the Federal Reserve to act as an "acceptance entity" that purchases loans - or securities backed by packages of loans - that are originated in accordance with criteria designed to remove credit bottlenecks in cases of otherwise sound and prudent credit risks.

12 The administration's American Jobs Act (AJA), proposed by the president on September 8th would, if enacted intact, be a valuable start to this process. We nevertheless find the AJA to focus too little on direct job creation and too much on the theoretical benefits of indirect hiring incentives and tax reductions. The latter would likely have spurred spending a few quarters back when the economy appeared to be on the mend, but are now more likely to be channeled towards savings in the present period of renewed anxiety. This paper is of course not meant to engage in debate over the efficacy of the AJA, and the AJA plan does include a modest infrastructure bank and a broader, although still-insufficient infrastructure spending program that we wholeheartedly endorse. Nevertheless, we have two principal areas of concern regarding the AJA direct spending elements: (a) that a significant portion of the spending is being funneled through existing state and agency programs as a way of getting funding to projects already on the boards, and (b) that the President has represented that the program will be fully funded through budget cutting elsewhere (which hopefully will be through cuts made far in the future of a long term "Super Committee" deal). Merely moving needed fiscal curatives from one budget line to another, or shuffling cuts from one year to the very next, will not do the trick if we are correct that this is a longer term struggle in which we are engaged.

13 We here distinguish between the increases in (a) aggregate wages certainly results from the reemployment of idle or underutilized workers and (b) increases in unit labor costs or individual wages. We are speaking of the former in this instance. 14 See, e.g., latest World Economic Forum ranking, as reported in Jason Lange, "U.S. Infrastructure Woes: A Roadblock to Growth," Reuters, August 16, 2011, available at http://www.reuters.com/article/2011/o8/16/uk-usa-economy-infrastructureidUSLNE77E04E20110816.

15 See Robert Hockett, Robert Frank, \& Laurence Seidman, Public Infrastructure Investment and the U.S. Fiscal Position, White Paper, New America Foundation, September 2011.

16 Specifically, we envision the expansion of the USACE-DCW as a key to avoiding inter-agency disputes. Federal and state highway authorities are well equipped to execute roadway improvements, and the USACE-DCW would interface extensively with highway authorities when major bridge and tunnel construction requires multiagency cooperation. Waterways, pipeline, energy, rail and major air transportation projects would be supervised, and if necessary project managed by the USACE-DCW. The USACE-DCW would be charged with project expediting and approvals processes (making projects shovel ready as quickly as possible) and ensuring that timelines favor more rapid utilization of labor as an accelerant during all phases of projects (including architectural and engineering phases).

17 See Hockett, Frank, \& Seidman, supra note 17.

18 See, e.g., 9/20/2011 Testimony of Laurie S. Goodman, Amherst Securities Group to the Subcommittee on Housing, Transportation and Community Development of the Senate Committee on Banking, Housing and Urban Affairs. 19 See, e.g., Robert Hockett, Home Mortgage Bridge Loan Assistance Act of 2011, Draft Statute, on file with the authors. 20 Previous U.S. administrations blocked efforts to increase the working capital of the IMF and the World Bank precisely because the proposed measures threatened Washington's pre-eminent position in these institutions, including its de facto sole veto power. That has turned out to be shortsighted, because we have been left with cash-strapped and ineffective international institutions. It also has placed a great burden upon the Federal Reserve to use U.S. monetary policy as a world crisis stabilizer, which in turn has contributed to the buildup of the large credit-fueled asset-price bubbles and busts of the past decade as 
discussed above. Finally, it has left the door open for the big surplus economies to use their sovereign wealth funds to influence the course of world capital markets.

\section{() (1) () (2)}

(C) 20II New America Foundation

This report carries a Creative Commons license, which permits re-use of New America content when proper attribution is provided. This means you are free to copy, display and distribute New America's work, or include our content in derivative works, under the following conditions:

Attribution. You must clearly attribute the work to the New America Foundation, and provide a link back to www.Newamerica.net.

Noncommercial. You may not use this work for commercial purposes without explicit prior permission from New America.

Share Alike. If you alter, transform, or build upon this work, you may distribute the resulting work only under a license identical to this one.

For the full legal code of this Creative Commons license, please visit www.creativecommons.org. If you have any questions about citing or reusing New America content, please contact us.

MAIN OfFICE

1899 L Street, NW

Suite 400

Washington, DC 20036

Phone 2029862700

Fax 2029863696
California OfFice

$92111^{\text {th }}$ Street

Suite 901

Sacramento, CA 95814

Phone 9164485189

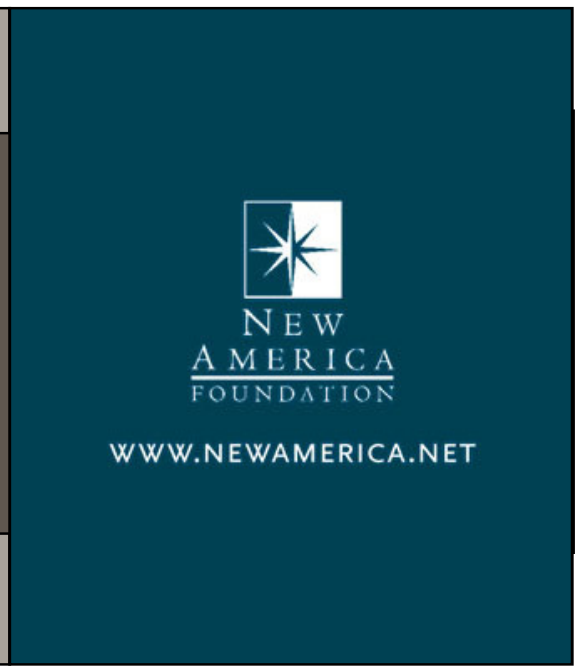

